\title{
1945 UTÁNI ISKOLATERVEZÉS MAGYARORSZÁGON. TÍPUSTERVEK ÉS EGYEDI ÉPÜLETEK ${ }^{1}$
}

\section{Bevezetés}

Írásom az 1945 utáni iskolaépítészet történetének egy kis szeletével foglalkozik, azon belül is szándékoltan nagyobb hangsúlyt fektet a korábban elhanyagolt típustervezésre. Ennek kapcsán természetszerűleg túl kellett lépni a szűkös szakirodalom felmondásán. Tanulmányomban szeretném bemutatni az iskolatervezést és magukat a terveket meghatározó, az épületek felépítését befolyásoló tényezőket. Nem titkolt célom, hogy a II. világháború utáni évek iskolaépítészetét - különösen a közvélekedés szerint elítélendő típustervezést - a megvalósult épületanyag és az iskolák típus- és egyedi tervein keresztül új megvilágításba helyezzem.

\section{Az oktatásügy épitkezéseinek történelmi háttere a paragrafusok alapján}

Az oktatásügyi építkezésekkel kapcsolatos első törvényi rendelkezések nem építésügyiek, hanem központi kormányrendeletek voltak, hisz az iskolakötelezettségre vonatkozó jogszabályok voltak azok, amelyek ezeknek az építkezéseknek a szükségességét és jelentős volumenét meghatározták. A háború után közvetlenül, 1945. augusztus 16-án született az a rendelet, amely a korábbi népiskola I-VIII. és a gimnázium, illetőleg a polgári iskola I-IV. osztálya helyett az ún. általános iskola megszervezéséről döntött. ${ }^{2} \mathrm{Az}$ ezt követő rendelkezések a 6-14, 6-15, illetve 6-16 éves gyermekeket kötelezték iskolába járásra. ${ }^{3} \mathrm{Ez}$ a korábbi iskolai szervezetet és tanmenetet felforgató szabályozás az iskolaépítést azért érintette érzékenyen, mert addig (főleg a vidéki társadalomban) a 13-14 éves korú gyerekek már munkaerőnek számítottak, ${ }^{4}$ vagyis az ő bevonásuk jelentősen növelte az iskolába járók létszámát, így a szükséges tantermek számát is. Az oktatás általánossá tétele, a müveltség demokratizálása deklarálódik az 1945 utáni első alkotmányban, vagyis az 1949. évi XX. törvényben. ${ }^{5}$ Ez kimondja, hogy a Magyar Népköztársaság biztosítja a dolgozóknak a múvelődéshez való jogát, amit a népmüvelés kiterjesztésével és általánossá tételével, az ingyenes és kötelező általános iskolával, közép- és felsőfokú oktatással, a felnőtt dolgozók továbbképzésével és az oktatásban részesülők anyagi támogatásával valósít meg. Az ugyanez évi XXV. törvényből pedig, amely az ország első ötéves népgazdasági tervéről (1950-1954) szól, a célkitüzés további részletezése is megismerhető. Eszerint „az 1950-54-es tervidőszakban fel kell számolni a volt uralkodó osztályok műveltségi monopóliumát, lehetővé kell tenni a dolgozó osztályok kulturális felemelkedését, a munkások, dolgozó parasztok és értelmiségiek gyermekeinek szakmai közép- és főiskolai képzését és az ország növekvő szakemberszükségletének ellátását. (...) [Ehhez pedig] biztosítani kell, hogy minden tanköteles gyermek valóban elvégezze a teljes nyolcosztályú általános iskolát, és a felsőbb osztályokban ne legyen lemorzsolódás. Ebből a célból új tantermek építésére, az iskolák jobb felszerelésére, új tanítói lakásokra stb. öt év alatt 322 millió forintot kell fordítani. (...) [szám szerint] a tervidőszak alatt 62 000-rel kell növelni az alapfokú iskolai oktatásban részesülő tanulók és 12 000-rel a pedagógusok létszámát". ${ }^{6}$ Az alapképzésen túl a cél eléréséhez fejleszteni kell a középiskolai és szakoktatást, és gyarapítani az egyetemek, főiskolák és az azokat kiszolgáló kollégiumi férőhelyek mennyiségét is. A közép- 
iskolákban ez alatt az öt év alatt 45 000-rel kellett emelni a tanulók számát, ennek érdekében 30 új gimnázium létesítésére volt szükség, elsősorban a bánya- és iparvidékeken. Az ipari tanuló iskolák tantermeinek számát az 1949-es 167-ről a tervidőszak alatt 500-ra, a tanmühelyek férőhelyeiét 3900ról 14 900-ra, a tanulóotthonokét 3500-ról 10 000-re, a mezőgazdasági szakoktatás alapfokú iskoláinak tanulószámát 97 000-rel, a középiskolákét 9000-rel kellett növelni. Az egyetemek újjáépítése mellett új intézetek, kísérleti laboratóriumok, munkahelyek létesítése a cél, valamint a 8000-rel több egyetemi tanuló férőhelyének megteremtése. A tanulmányok folytatásának segítésére és a lemorzsolódás megakadályozása érdekében hozták létre az állami kollégiumok hálózatát. Az általános iskolai kollégiumok férőhelyeit 1700-zal, a középiskolásokét 3500zal, a főiskolaiakat 1500-zal szándékoztak bővíteni. Összegszerűen az építőipar 21345 millió Ft értékű beruházásaiból 1391 millió Ft-ot szántak kulturális célú építkezésekre. ${ }^{7}$

Ennek a törvénynek az 1951. évi módosítása jelentős mértékben emelte az ipari tanuló otthonok, középiskolai és egyetemi, főiskolai tanulói létszámokat, a kollégiumi férőhelyek számát. ${ }^{8} \mathrm{~A}$ későbbi költségvetési törvényekben tovább nőtt a kulturális célú beruházásokra fordítható összegek százalékos aránya és összértéke. Az 1954. évi IV. törvény a költségvetés 21, az 1955. évi I. törvény 22,9, az 1956. évi II. törvény pedig $27,3 \%$-át irányozta elő szociális és kulturális célokra és létesítményeinek fenntartására, hálózata bővítésére. ${ }^{9}$ Bár az 1957-58 közti időszakra előirányzott összeget nézve némi visszaesés tapasztalható, ${ }^{10}$ az 1958-1960-as, hároméves tervidőszakról szóló törvény már 3500 általános iskolai osztályterem megépítését irányozza elő. ${ }^{11}$

$\mathrm{Az}$ oktatási intézmények építésével kapcsolatos hivatalos retorikában 1961-ben állt be fordulat. A második ötéves tervről szóló törvény már az eddig elért eredmények taglalásával kezdi bevezetőjét. Kiemeli, hogy 1958 és 1960 közt „fejlődött az oktatási hálózat, növekedett a tantermek száma. Az előirányzott 3500 általános iskolai tanteremmel szemben több mint 4000 tanterem épült" ${ }^{\prime 2}$ A törvény szerint a lendületnek töretlennek kell lennie, hiszen 1965-ig további 3300 általános iskolai és 800 középiskolai osztálytermet, valamint 1300 középiskolai diákotthoni férőhelyet szükséges teremteni. ${ }^{13}$ Ennél is jobban cseng Kádár János 1962. évi beszéde, miszerint „a mi iskolatípusaink közül a középiskola az, amelyikkel népünknek és államunknak a legközelebbi években nagyon sok dolga lesz. [hiszen] A felszabadult magyar népnek és a népi államnak első feladata az volt, hogy a legelemibb oktatási szervezetet rendbehozza és olyanná tegye, amilyennek lennie kell, azaz megteremtse az általános iskolát. Ez nagyjából megoldódott. A törvény szerint, a jog szerint, a lehetőség szerint minden gyermek elvégezheti a nyolc általánost. (...) Ezért mondom, hogy alapjában az általános iskola kérdése meg van oldva hazánkban. Most, hogy úgy mondjam, a soros: a középiskolai oktatás fejleszté$\mathrm{se}^{\prime \prime}{ }^{14}$ Ezt az iránymutatást maradéktalanul követi a következő ötéves terv (1966-1970) megfogalmazása is: „a szakmunkásképző iskolák és a középiskolák hálózata 1200-1300 új tanteremmel bővüljön. Növelni kell a kollégiumi, a diákotthoni és a mühelytermi férőhelyeket." 15

És bár 1970-ben is tendencia maradt az iskolahálózat bővítése mindamellett, hogy ekkor került sor törvényi szinten is az óvodák nagyobb arányú fejlesztésére. ${ }^{16}$ Az 1975-ös ötödik és az 1980-as hatodik ötéves tervre vonatkozó rendelkezésekben az oktatás minden területére kiterjedő nagymértékű építkezések célkitüzései szerepelnek. Előbb 70-75 000 óvodai, 3000-3200 általános iskolai és 7500-8000 szakmunkás diákotthoni férőhely, 4000-4500 osztályterem, 400-450 szakmunkásképző intézeti osztály- és előadóterem, mintegy 2000 tanműhelyi munkahely megépítése volt tervben. ${ }^{17}$ Majd 1980-ban 30-35000 új óvodai férőhely, 5500-6000 általános iskolai osztályterem megvalósítását irányozták elő. ${ }^{18}$

\section{A megvalósitás}

A továbbiakban az iskolaépületek (közelebbről az általános iskolák) tervezésének és megvalósításának azokat az aspektusait veszem sorra, amelyek eltérnek a megszokott múvészettörténeti megközelítéstől. Célom ezzel az, hogy bemutassam: a szabályozás és építésirányítás mikéntjének vizsgálata nemcsak az építészet alapvetően történeti szempontú vizsgálatához teremt új lehetőségeket, hanem az épületanyag formai (és építészeti minőségi) megítéléséhez is. ${ }^{19}$

\section{Az iskolaépületekre vonatkozó előirások}

Az iskolaépületek egyrészt kétségtelenül a tudásátadás helyei, sőt téri minőségükben a kultúraközvetítés eszközei, ${ }^{20}$ ám megvalósításuk mikéntjében meghatározóbbak az építésügyi, tüzrendészeti, használati biztonsági és egészségügyi előírások, mint az azoknál jóval gyakrabban változó pedagógiai normák, sőt vizuális elvárások. Másrészt az is nyilvánvaló tény, hogy „minden épületnek, vagy építménynek meg kell felelnie a rendeltetésének, a benne és a környezetében tartózkodók egészség-, 
élet- és vagyonbiztonsághoz szükséges müszaki követelményeinek", ${ }^{21}$ ami azzal is jár, hogy minden időben és épülettípusban adottak bizonyos kötelező alapterületek, belmagasságok, formai kialakítások, amiket - úgy is, mint minimális programot be kell tartani.

Épületeinek megvalósítási szabályozására az Egészségügyi Minisztérium (EüM) érvényben lévő előírásai, a többszörösen módosított Országos Építésügyi Szabályzat (OÉSz) (csupán a fő vonalakat rögzítő) fejezete és a Magyar Országos Tervezési Irányelvek (MOTI) általános iskolákra vonatkozó elöírásai voltak mérvadóak. ${ }^{22} \mathrm{~A}$ továbbiakban ezekből az előírásokból csak azokat a passzusokat idézem, amelyek az épület vagy az iskolaudvar méreteit, kialakítását megszabták, s így közvetve vagy direkten meghatározták az épület megjelenését.

Az EüM utasításai előírták az iskolák közegészségügyi szempontból megfelelő elhelyezését, és kitértek a tantermek megvilágítására, helyére és a zajszennyezés lehetőségére is. Eszerint: „Egy tanulóra legalább 5 négyzetméter iskolaudvar terület jusson. $\mathrm{Az}$ iskolaudvar legkisebb mérete 400 négyzetméter legyen. Az iskola udvarának csak kisebb része legyen fásított, nagyobb része szabad, pormentes térség legyen." ${ }^{23} \mathrm{~A}$ tantermeket nem árnyékolhatják fák, és az épületet legalább 10 méter széles előkertnek kell elválasztania az utcától. Tanterem, tanulószoba alagsorban nem lehet. ${ }^{24} \mathrm{Az}$ épület tájolásánál törekedni kell arra, hogy a tantermek „,a napi oktatási idő alatt közvetlen napfényt csak rövid időn át kapjanak. (...) A tanteremnek téglalap alakúnak kell lennie. A hosszúság-szélesség aránya 4:3; esetleg 5:4. Rajz és különleges szakcélokra szolgáló oktatótermek kivételével kilenc méternél hosszabb tantermet nem szabad építeni. (...) Egy tanulóra a tanteremben 1,25-1,50 négyzetméter alapterületet kell számítani. Egy tanteremben a tanulók létszáma átlagban 40 legyen, de az 50-et ne haladja meg." ${ }^{25}$ A falaknak világos színúeknek, a mennyezetnek fehérnek kell lennie. „A tanterem ajtaja folyosóra vagy a pihenőhelyiségbe nyíljék. Ne nyíljék közvetlenül az előcsarnokba, árnyékszék, falatozó vagy más mellékhelyiség közvetlen közelébe. Ha a tanteremben csak egy bejárat van, annak lehetőleg a nevelő helyéhez közel kell lennie. Emiatt azonban nem szabad a padokat úgy helyezni, hogy a tanulók jobbról kapják a természetes megvilágítást."26 A nevelők szobájában nevelőnként 5 négyzetméter terület jut, de a szoba alapterületének 12 és 50 négyzetméter közt kell lennie. ${ }^{27}$ "A zsibongóban egy tanulóra 0,65 négyzetméter alapterület jusson. A zsibongó tervezésénél figyelembe kell venni azt, hogy milyen nagyságú terület áll udvar céljára rendelkezésre. Kisebb udvarterület esetén a zsibongót nagyobbra kell méretezni. A zsibongó világos, jól szellőztethető helyiség legyen. A folyosó szélessége 2,5 m, ahol zsibongót nem terveztek, ott 4 m." ${ }^{28}$ Ezenkívül rendelkezik a szabályozás a tanulók ruházatának elhelyezéséről, az árnyékszékek tanulók számára vetített számáról és kialakításáról, az iskolafürdők építéséről, az iskolai bútorzatról, az étkeztetés megoldásáról, az ivóvíz-ellátottsággal, a megvilágítással, szellőztetéssel, fütéssel, takarítással és szemétszállítással kapcsolatos kérdésekről is. Végül pedig a végrehajtás felsorolja a szabályzatnak azokat a pontjait, amiket „új iskolaépület tervezésénél és létesítésénél, meglévő iskolaépület átalakításánál, illetőleg bővítésnél (...) minden esetben be kell tartani". ${ }^{29}$ Vagyis lényegében az általam felsoroltak mindegyikét.

Az 1962-es Országos Építésügyi Szabályzat ${ }^{30}$ az épületekkel kapcsolatos, elsősorban statikai, anyaghasználati, víz-, hő- és tűzvédelmi, zaj- és levegőszennyezettségre vonatkozó előírásokat tartalmazza. Ebben az iskolaépület tömegtartózkodásra szolgáló közcélú épület. ${ }^{31}$ Mint ilyen, bejáratának szélessége 1,4 és 2 méter közti, magassága legalább 2,2 méter lehet, és kifelé kell nyílnia, de nem lehet körforgó vagy tolóajtó. Szélfogót pedig kötelező építeni. ${ }^{32}$ A lépcsőház „helyét épületen belül úgy kell meghatározni, hogy a forgalom az irányába terelődjön, méreteinek meg kell felelni a szintkülönbség megerőltetés nélküli legyőzése és a forgalom sűrűsége szerint megállapítható követelményeknek", ${ }^{33} \mathrm{~s}$ az emeletszint bármely pontjától legfeljebb 30 méter távolságra lehet. Az OÉSz szabályozza a mellékhelyiségek, fütő- és tárolóhelyiségek közösségi terekhez való viszonyát és méreteit is. A foglalkoztató-tanulóhelyiségekkel kapcsolatosan pedig az alábbiakat szabja meg: csak földszinten vagy emeleten lehetnek (kivéve a műszaki oktatásra szolgáló helyiségeket). Az egy före eső legkisebb terület 6-18 éves korú használók esetén $1,2 \mathrm{~m}^{2} / \mathrm{fö}$, a térfogat pedig $4 \mathrm{~m}^{3} /$ fó lehet. „A helyiség ürmagassága legfeljebb 8 fő férőhelyig legalább 2,65 méter, ezenfelül 3 méter legyen."34 A tájolásnak K-DK-D-DNy-inak kell lennie. Az ablakfelületnek a helyiség felületéhez viszonyítva 1/6-nak vagy ennél nagyobbnak kell lennie. Nem alkalmazhatók franciaablakok, és az ablakok közti pillérek szélessége nem lehet 0,8 méternél nagyobb. Az 1974-es ÉVM rendelkezés annyit tesz kötelezővé, hogy a tantermek belmagassága legalább $3 \mathrm{~m}$, alapterülete legfeljebb $56 \mathrm{~m}^{2}$-es lehet, a zárt zsibongóban pedig egy före minimum $0,8 \mathrm{~m}^{2}$ kell jusson. ${ }^{35}$

A MOTI mindezeket alkalmazva 40-42 diákkal számolva $52 \mathrm{~m}^{2}$-es alapterületet és 3,2 m ajánlott belmagasságot ír. Mindkét szám valamivel na- 
gyobb, mint a negyvenkét főre megadott minimálisan szükséges. ${ }^{36}$

Korszakunk első felében a nagyobb iskolák tervezőinek figyelembe kellett vennie a fiúk és lányok elkülönített oktatásának szükségességét is (pl. Csepel-Csillagtelep kétszer 12 tantermes iskolája). ${ }^{37}$ A koedukált oktatás azokon a helyeken, ahol nem volt külön iskolaépület a két nem számára, már korábban is létezett, de csak a hatvanas évek elejétől vált általánossá.

\section{A tervezést meghatározó politikai jellegú előirások}

Már az első ötéves terv is tartalmaz a nagyszabású építkezések megvalósításának könnyítését célzó előírásokat. A beruházások hatékonyságának növeléséhez világossá vált, hogy „a tervezést az ésszerűség és gazdaságosság, valamint az egységes felfogás útjára kell terelni. Ez azt jelenti, hogy alapos meggondolások alapján kell meghatározni az építkezések tervezési és építési feladatait." ${ }^{38}$ Nemcsak az építőipar átszervezése, a gépesítés fejlesztése, a munkamódszerek korszerüsítése, hanem az építészeti alkatrészek, szerkezetek előregyártása, az építmények tipizálásának megszervezése is az előírások közt szerepel. ${ }^{39}$ Ennek megfelelóen 1950-1951-ben megkezdődött az Építésügyi Minisztérium (ÉM) irányítása alatt az állami tervező vállalatoknál - mint a KÖZTI, az IPARTERV, a LAKÓTERV - a különböző gazdasági területekhez, társadalmi szükségletekhez tartozó típustervek kidolgozása. Az elkészült terveket folyamatosan publikálták, s megszülettek az ehhez tartozó ÉM utasítások is. Eszerint a típusterv-katalógusok „,tartalomjegyzék[é]ben felsorolt típustervek kötelező alkalmazásba vételét az Építésügyi Minisztérium 1952. évi 42. sz. Miniszteri Utasítása [sic!] rendelte el. Ugyanez az utasítás hatálytalanította a típustervek kötelező alkalmazásba vételéről szóló 3611-62/1951.(IV.24) É.M. sz. rendeletet." ${ }^{40}$ Borbíró Virgil 1954-es cikkéből azonban megtudjuk egyfelől azt, hogy „a tervezés ilyetén szabályozására készült elöírások nem voltak tökéletesek, nem voltak eléggé célszerűek és gazdaságosak, másfelől, hogy azokat sem az építtetők sem a tervezők nem tartották be azokon túlmenő terjedelmú épületeket terveztek [sic! ]". ${ }^{41}$

A nagyobb épületek tervezése komoly többletkiadással járt, így logikusnak tünik a kormány azon, 1958-as határozata, ${ }^{42}$ amelynek „értelmében az érvényes típustervek alkalmazása az állami beruházásoknál kötelező és abban az esetben, ha típusterv rendelkezésre áll, egyedi tervet készíteni nem szabad. A Beruházási Bank (...) a hitel fo- lyósítását köteles megtagadni, ha a rendelkezésre álló típusterv ellenére - az ÉM engedélye nélkül - egyedi terv készül. Ezen túlmenően a beruházó és a tervező is anyagi felelősséggel tartozik és őket a keletkezett kár megtérítésére kell kötelezni. (...) A típustervek dokumentációit - azok jóváhagyása után - az ÉM Dokumentációs és Nyomtatványellátó Vállalatnál (Budapest, Kossuth Lajos u. 17.) lehet beszerezni". A típusterveket felhasználáskor a helyszínre kellett alkalmazni, amin az egyes tervek változatai közül a legmegfelelőbb kiválasztását értjük (pl. a telek közmúellátottsága alapján), illetve a helyszíni viszonyokhoz adaptálását (ami lehetett az épület tájolásának és az utcavonalhoz igazodás kérdésének egyeztetése). ${ }^{43}$ Dr. Gyöngyösi István az 1960-as cikkében így érvel a típustervek és a tipizálás mellett: „A tipizált építkezések lehetővé teszik a fejlettebb építéstechnika alkalmazását, megakadályozzák az anyagpazarlást, elősegítik az új gyártmányok, építési anyagok, előregyártott elemek, összefüggő szerkezetek felhasználását. A típustervek biztosítják, hogy az építkezések jelentős része gazdaságos és funkcionálisan jó legyen, mentesítenek az azonos feladatok ismételt elvégzése alól, a beruházások tervigényei gyorsabb kielégítését teszik lehetővé." ${ }^{44}$

A típustervek törvényi szintű kötelezővé tételére 1964-ben került sor. Eszerint: „A többször ismétlődő, azonos vagy hasonló rendeltetésű szerkezetekre, építményrészekre (szekciókra) és építményekre típustervet kell készíteni. A típustervek alkalmazása állami szervek építkezései esetében kötelező; jogszabály más építtetők építkezései tekintetében is elrendelheti a típustervek kötelező alkalmazását. Az építésügyi miniszter e kötelezettség alól indokolt esetben felmentést adhat." ${ }^{45}$ A törvény lényegében megismétli a 12-13 évvel azelőtti építésügyi miniszteri utasítást, illetve a 6 évvel korábbi kormányhatározatot. Lehet találgatni ennek a bürokratikus, ámde a végrehajtást nyomatékosító lépésnek az elképzelhető okait. Vajon csak retorikáról van szó, és nem szolgál mást, mint a korszakra végig jellemző gazdaságosság, takarékosság hangsúlyozását? Vagy elképzelhető, hogy a típustervekkel szembeni ellenállás túl sokszor nyitotta meg az Építésügyi Minisztériumi engedélyezés kiskapuját? Esetleg ekkorra valósultak meg mindenütt a típustervekben megkívánt építési feltételek (pl. elöregyártott vasbeton gerendák, béléselemek)? Korábban ugyanis a helyi körülmények egyszerúen nem tették lehetővé, hogy a típustervekben lefektetett technológiát alkalmazzák. 1958-ban Hegedús Ernő a vidéki iskolák kapcsán az alábbi problémára hívta fel a figyelmet: „Az új típustervek szerkezeti szempontból [kiemelés az eredeti szerint - L. E.] a régiekkel azonos 
elv alapján terveződtek. A födémek előregyártott gerendák között béléstestes kivitelben, a tetőszerkezet pedig előregyártott vasbeton szaruzattal készült. Az előregyártás szempontjainak fokozottabb érvényesítése érdekében, még a főpárkány is helyszíni előregyártással lett megtervezve. Időközben azonban a vidéki kisiskolák kivitelezését az állami építőipar profilírozása következtében túlnyomó többségében, most már nem az állami építőipari vállalatok, hanem a megyei Tatarozó Vállalatok és gyakran az Építőipari KTSz-szek [sic!] végzik. Ezek a kivitelezők nem rendelkezvén megfelelő gépesítéssel a vasbeton elemek beemeléséhez, az ilyen iskoláknál szinte kivétel nélkül a fedélszéket vagy átterveztetik, vagy azokat egyszerűen fából építik meg. (Gyirmót, Sághalomalja, stb.) Manapság gyakran előfordul az az eset is, hogy típustervek alapján (és ez még a jobbik eset), társadalmi munkában a község maga építi meg az iskolát, természetesen a rendelkezésre álló legprimitívebb építési eszközökkel." ${ }^{\prime 6}$ De még 1963-ban is előfordultak kivitelezési problémák: így pl. az ikersejt téglákat úgy építették be, hogy a téglák lyukai vízszintesbe kerültek (püspökladányi gimnázium), vagy nem ismerték a kiadott tömítést (nádudvari nyolctantermes iskola). ${ }^{47}$ Mivel eredeti kérdésfelvetésünket, szorosan vett témánkat a törvényhozók észjárásának kifürkészése nem feltétlenül viszi előre, ennek az izgalmas, de messze vivő szálnak a felgombolyítását meghagyhatjuk egy későbbi történeti kutatásnak.

A típustervek és a célra szabott tervezóvállalatok kérdése

Az 1951-es katalógusban nincs iskolaterv, de az 1952-esben már három különböző méretű is helyet kapott. Az egy- és kéttantermes 1951-es terv Rácz Györgytől, a négytantermes 1952-ből való, annak tervezői: Schömer Ervin és Medvedt László. ${ }^{48}$ A kisebbek tervei csupán alaprajzok, a homlokzati megoldásokról nem tájékoztatnak. A négytantermes iskola kétszintes, kontyolt nyeregtetővel, homlokzata aszimmetrikus elrendezésü, bejárata lépcsővel megemelt, két oldalán kváderezéssel, felső záródásán íves párkánnyal hangsúlyozott. A földszintjén találhatóak a közösségi terek, irodák és a zsibongó, az emeletén a tantermek, a szertár és az emeleti zsibongó. A katalógus más terveinek a népi és a történeti építészet formakincséből merítő megoldásaihoz képest ez a homlokzatterv formailag visszafogott. A tantermek 54, a zsibongók 80-110 négyzetméteresek.

Az első, 1951-1952-es típusterv-katalógusokban a tervezők neve mellett még nem szerepeltek az anyavállalatok nevei, a későbbiekben viszont nem- csak, hogy ugyanazon tervezőnevek mellett ugyanabból az évből is állhatott más vállalatnév, de a tipizált középület típusa sem feltétlenül kötődött az azt tervező vállalat nevében feltüntetett profilhoz.

Hogy miért van ez, amikor az építés- és közmunkaügyi miniszter 1949. január 14-én, illetve 21-én rendelkezett a magasépítő-ipari nemzeti tervező vállalatok felállításáról, ${ }^{49}$ ezt követően pedig 1950 körülre ki is alakult az állami tervező szervezet egységeinek hálózata, s ebben az évben már meg is szervezték a beruházó tevékenységet is folytató tárcák technológiai és tervező szerveit is? A választ Valentiny Károly 1958-as cikke adja meg. „Az 1948-tól szervezett építési tervezést végző szervek profilja [eredetileg] élesen elhatárolt volt. Később, főleg az első 5 éves terv első éveiben, a megnövekedett beruházási feladatok műszaki tervellátása, továbbá az egyetemi és egyéb felsőoktatási intézmények tanszékeinek jövedelem-kiegészítése érdekében, végül a vidéki tanácsi szervezet erősítésének céljából több jogszabály a szervezet tágulását írta elő. (...) [Így] a tervezői szervezet ma túlságosan széttagolt és jórészt egészségtelen szervezési elveken épült ki. a) A tervezés mind a beruházással, mind a kivitelezéssel egy szervezeti egységben a népgazdasági érdekek háttérbeszorítását eredményezi; mert elsődleges céljuk a szervezet termelésének minden áron való előmozdítása (...) c) Tervező csoportok, részlegek tervezési munkáinak egységes irányítása, ellenőrzése szinte megoldhatatlan. Még több hiányosság, sőt törvénysértés és korrupció bújik meg a tervező mérnöki munkaközösségek vállalásai mögött. 1950-58. évek alatt a tervező szervek profiljai elmosódtak, sőt nagymértékben összekeveredtek. Ezt a folyamatot elősegítette az az egészséges szemléletváltozás is, amely a tervezőszervek irányításában a szervek közötti verseny érdekében, a túlzott profilvédelemről lemondott." ${ }^{50}$ Valentiny elég szókimondóan fogalmazza meg a profiltisztaság megszűnésének okát. Ám érdemes odafigyelni az általa használt szókapcsolatokra: megoldhatatlan egységes irányítás és ellenőrzés, a munkaközösségek vállalásainak korrupcióig menő módja (aminek oka a szervezetekkel szembeni tervteljesítési elvárás), versus az egészséges szemléletváltozás, ami teret engedett a versenyzésnek. Mind ugyanannak a sajátos helyzetnek a leírása, ami az akkori magyar valóságot jellemezte: igény a túlzott központi irányításra, ami azonban a helyi slendriánságon és ügyeskedésen elbukik, de ennek ellenére időnként még kedvező eredményt is hozhat.

A típustervezés központosított intézményesítésének története úgy kezdődött, hogy 1953-ban létrehozták az ÉM Műszaki Tervezési Főosztálya 
felügyelete alatt tevékenykedő Tervezésfejlesztési és Típustervező Intézetet (TTI), először a Lakóterv szervezetén belül, majd 1961-től önálló intézményként. „Fő feladatköre az építéstervezési kutatás: kísérleti épületek, építmények, szerkezetek, prototípusok kialakítása, továbbfejlesztése és megvalósítása, valamint az ezzel kapcsolatos müszaki fejlesztés lebonyolítása [volt]. (...) Másodlagos feladatköre: (...) a tervezési vonatkozású tájékoztatók, segédletek szerkesztése és kiadása." ${ }^{51} \mathrm{Az}$ intézet 30-35 tervezővállalatot, kutatóintézetet, kivitelező és gyártó vállalatot vont be munkájába. ${ }^{52}$ A TTI középületekkel kapcsolatosan a KÖZTI-vel együttmüködve végezte el a szükséges funkcionális vizsgálatokat, dolgozta ki a méret- és szerkezetegységesítést, lehetővé téve ezzel szerkezeti rendszerek kidolgozását is. ${ }^{53}$ Azokban az években ugyanis már nem pusztán típustervezés folyt, ugyanis a típustervezés fogalmát felváltotta egy sokkal szélesebb körű tevékenységet jelző fogalom: a tipizálás. Ez a szó az Építésügyi törvény részletes indoklásában a "gyártási és üzemeltetési technológiák lehetőség szerinti egységesítését" ${ }^{54}$ jelenti. A TTI által - a KGST közelgő Harmadik Típustervező Konferenciája apropóján - 1964-ben megjelentetett kiadványban pedig azt hangsúlyozták, hogy „az Intézet lelkes kollektívájának az a helyes meggyőződése, hogy feladatuk az építés módjában olyan változás létrehozása, amely a népgazdaság számára hasznos módon csökkenti az építőanyag, szerkezet, épület és építmény előállításához szükséges társadalmi munkamennyiséget és javítja az építési munka feltételeit. E felfogásukkal munkájukat egyre jobban a múszaki haladás szolgálatába állítják”. ${ }^{55}$ A TTI tehát „a különböző területen jelentkező, s az adott időszakban lehetséges igényszintek rögzítése, (...) azok alapján az adott időszakra érvényes, lehetséges követelményekként rendszerbe foglalt elhatározások, illetve a megvalósítás számára előírások" [Kiemelések az eredeti szerint - L. E.] készítésével, a "funkcionális jellegü kutatások rendszerezettebbée ${ }^{\prime \prime 6}$ tételével a típustervezést tipizálássá fejlesztette, s ezzel megnyitotta az utat az építésiparosítás, a sorozatgyártás, a tömeges építés rohamos fejlődéséhez. Az egyes tervezővállalatok pedig továbbra is részt vehettek a profilukba vágó típustervek kialakításában.

$\mathrm{Az}$ sajnos csak bizonytalanul rekonstruálható, hogy a TTI és az egyes tervezővállalatok közt hogyan is müködött pontosan a feladatok leosztása, miként is történtek a megbízások. A kérdés az, hogy a közvetlen utasítás, a kézi vezérlés volt elsődleges, illetve létezett-e valamilyen versenyhelyzet az egyes vállalatok közt? Az azonban világos a típustervekkel kapcsolatos elsődleges forrásokból, vagyis magukból a típusterv-katalógusokból, hogy az iskolatervezésben a hatvanas évek közepén is érvényben volt még a Valentiny Károly 1958-as cikkéből megismert munkavállalási gyakorlat, és a szépen kitalált, tiszta profilú tervezővállalati struktúra továbbra sem múködött. Az 1960-tól már épülettípusonként kiadott, ún. Müvelódésügyi Típustervek Katalógusa szerint döntően KÖZTI-sek, Reischl Péter (KÖZTI és TTI), Kiss István, Brjeska István, Azbej Sándor, Perczel Dénes, Zdravics János, Tiry György, Mányoky László és Mueller Éva készítették az iskolák és művelődési házak típusterveit. De csak döntően, és nem kizárólagosan, hiszen 1962ben Köves Emil (Pécsterv), 1965-ben pedig Vass Zoltán (Általános Épülettervező Vállalat) is jegyzett épülettervet, és csak a tervek kb. egyharmada TTI-s tervezőé (Szabó Iván, Ferenczy Béla).

\section{Az iskolák típusterveinek története}

A szakirodalomban ${ }^{57}$ divatos pejoratív felhangokkal beszélni a típustervekről, és kárhoztatni a kort, amely az építészszakmát ezek készítésére, a lakosságot pedig az egyenépületek használatára kényszerítette. Igazságosabbak azonban azok a vélemények ${ }^{58}$ amelyek arra figyelmeztetnek: a típustervezés nem a szocialista korszak uniformizálásának terméke.

Oktatási épületek kapcsán a történet a 18. századig nyúlik vissza, és természetszerüleg összekapcsolódik a közoktatás történetével. Elsőként 1777ben a Ratio Educationis rendelkezett az oktatás nagymérvű fejlesztéséről, ami az iskolaépületek kialakításának szükségességével is járt. ${ }^{59}$ Majd pedig az 1868-as, a népiskolai közoktatás tárgyában hozott törvénycikk, ${ }^{60}$ vagyis az annak következtében szükségessé vált építkezések kapcsán jelentek meg ún.

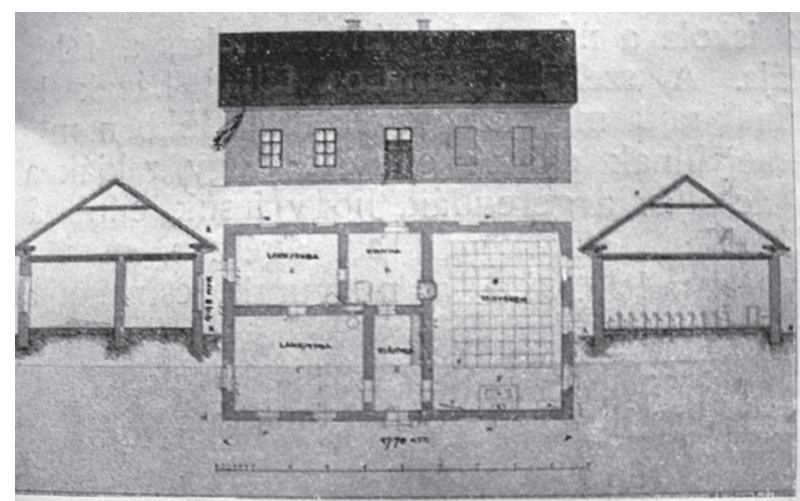

1. ábra. Szabványterv 1874. évből.

1. Iskola szabványterve, 1874.

Közli: Sváb Gyula, Magyar Mérnökés Épitész Egylet Közlönye XLVIII. 1914/2, 17. 


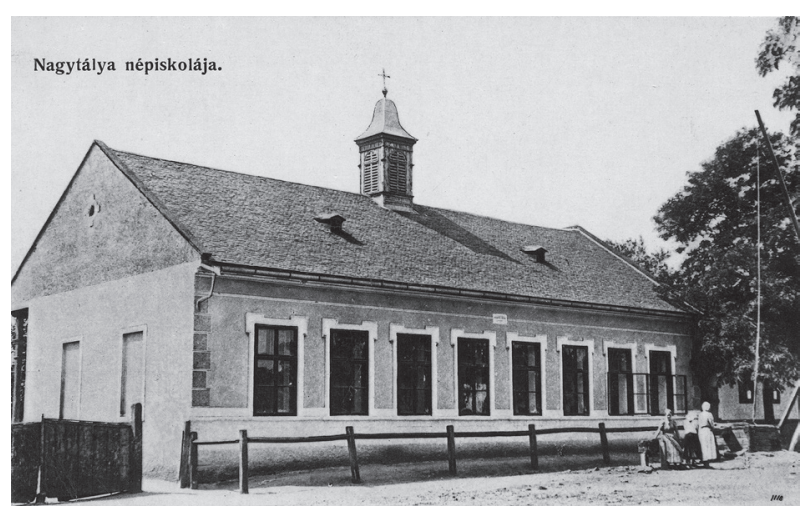

2. Baumgarten Sándor mintaterve alapján: Nagytálya, kéttantermes, tanitólakásos iskola. Vallás-és Közkoktatásügyi Minisztérium: Kisdedóvodai és népiskolai épitkezési mintatervek gyüjteménye, 1897. Képeslap, magántulajdon

mintatervek. Ezek a Gönczy Pál minisztériumi főtanácsos neve alatt kiadott tervek 1870-től voltak forgalomban. 1897-től pedig a Vallás- és Közoktatásügyi Minisztérium bocsátott ki szabványterveket. ${ }^{61}$

A Kultuszminisztérium 1888 és 1908 közötti iskolaépítéseihez a terveket Baumgarten Sándor és

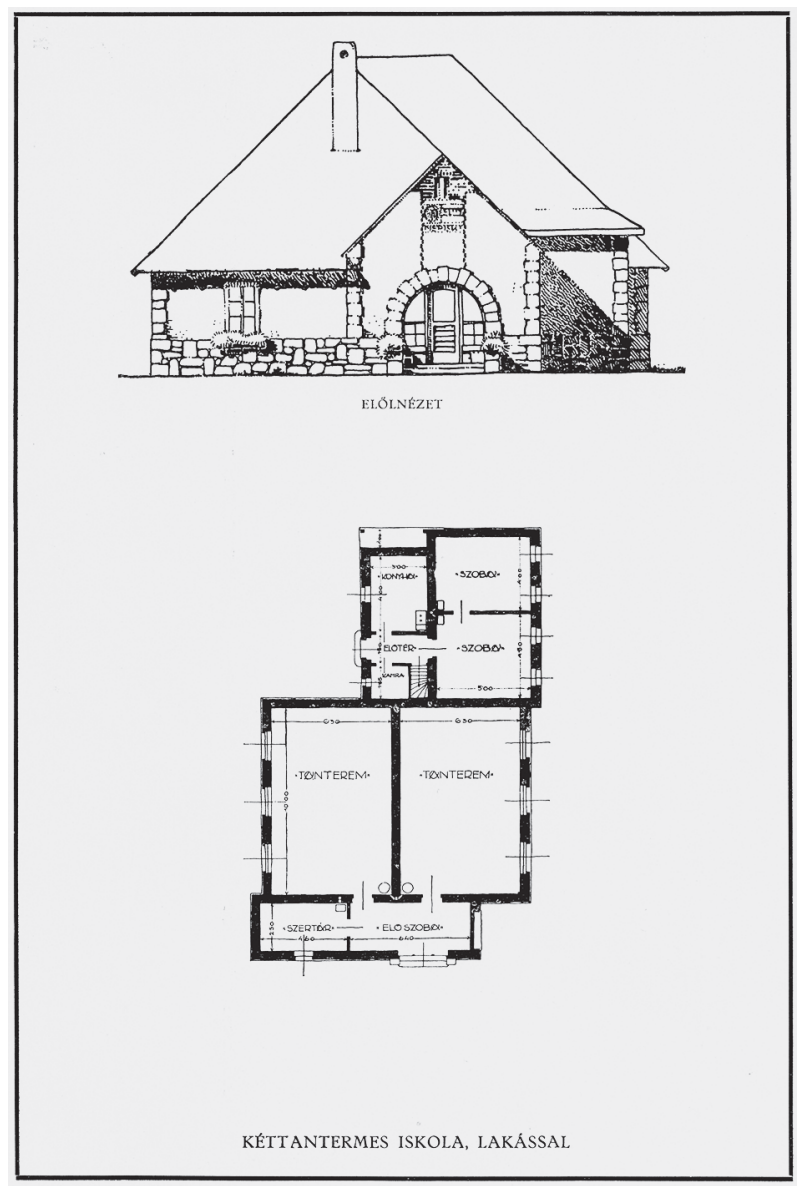

3. Sváb Gyula: Kéttantermes iskola mintaterve. Magyar Építőmüvészet 10. 1927/ 1, 17.
Herczeg Zsigmond tervezte és kivitelezte. Ezek egy része kisdedóvók és népiskolák mintaterve volt, de készítettek egyedieket is elemi, polgári és kereskedelmi iskolák, bába-, tanító- és óvónőképzők, gimnáziumok és főreáliskolák létesítéséhez. ${ }^{62}$ A 20. század eleji, több helyen is folyt iskolaépítési akciók kapcsán, noha jelentős épületanyagot jelent, ${ }^{63}$ tudomásom szerint nincsenek adatok arról, hogy ezek közül mennyi épült típustervek alapján. Ennek oka, hogy az építészettörténeti szakirodalom mindmáig csak az egyéni invenciót felmutató épületeket tartja említésre, kanonizálásra érdemesnek.

Az 1921-es, az iskoláztatási kötelesség teljesitésének biztositásáról rendelkező XXX. törvénycikk kapcsán készült felmérés azt mutatta, hogy helyhiány miatt a tankötelesek egy része nem is tudta megkezdeni tanulmányait. ${ }^{64}$ Ennek megoldására iskolák telepítését rendelték $\mathrm{el}^{65}$ a vallás- és közoktatásügyi miniszter irányításával statisztikákból prognosztizálták a következő évek tanköteleseinek létszámát, s ez alapján megállapították, hogy 3500 tantermet és 1750 tanítólakást kell építeni. Az iskolahálózat kiépítése céljából a törvényhatóságok közigazga-

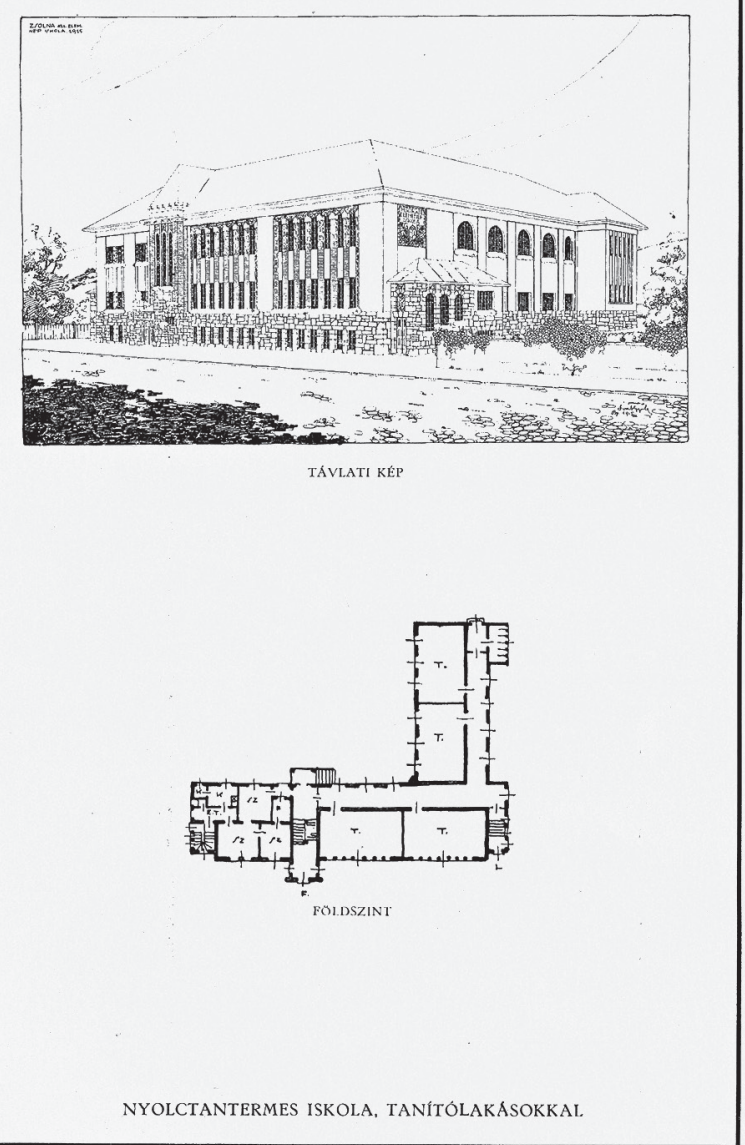

4. Sváb Gyula: Nyolctantermes iskola mintaterve. Magyar Építömüvészet 10. 1927/ 1, 27. 
tási bizottságai megkapták a minisztérium által kidolgozott tervezetet, amelyben kijelölték azokat a helyeket, ahová népiskola építését tervezték. Ezután egy, a közigazgatási bizottság kiküldöttjéből, az államépítészeti hivatal vezetőjéből és a királyi tanfelügyelőből álló csoport helyszíni szemlét és az érdekeltekkel megbeszélést tartott, amelyen egyeztették a hivatalos adatokat a helyi viszonyokkal és szükségletekkel, meghatározták, hogy milyen (felekezeti, vagy községi, állami érdekeltségü) legyen az iskola, hol legyenek a körzethatárok, és hol álljon az épület. ${ }^{66} \mathrm{~A} 3$. § pedig rendelkezett az állam szerepvállalásáról, miszerint „a törvény alapján létesülő iskola építéséhez az állam építési (átalakítási) terveket és előméret-költségvetéseket ad; a tervek használata kötelező". Az állam ezenkívül gondoskodik az illetékes államépítészeti hivatal útján az építés ellenőrzéséről és felülvizsgálásáról. „(...) 11. § (...) Az e törvény alapján végrehajtandó építkezésekre nézve a vallás- és közoktatásügyi miniszter az államépítészeti hivataloknak részletes utasítást ad és normálterveket és előméret költségvetést bocsát rendelkezésükre" ${ }^{67}$ A 18 elemi iskolai és 3 óvodai mintatervből - melyet ingyen bocsátottak az építtetők rendelkezésére - a kettőnél több tantermesek tervezését magántervezőkre bízták, az egy- és kéttantermes népiskolákét Sváb Gyula, a Minisztérium Müszaki osztályának alkalmazottja készítette. ${ }^{68}$ Ennek az iskolaépítési programnak köszönhetően 1930-ra elkészült 374 teljesen új tanyasi iskola, 196 óvodai foglalkoztató, 76 óvónői lakás és 25, addig iskolátlan községben épült elemi iskola ${ }^{69} \mathrm{~A}$ koalíciós időszakban az új, nyolcosztályos általános iskolai rendszernek megfelelő típustervek készítésével Györgyi Dénest és Kozma Lajost bízták meg.

Bepillantva a 19. század végi és a 20. század első felében létező állami iskolaépítési gyakorlat számaiba meglepő, hogy mekkora a hasonlóság a 20. század második felével. (A II. világháború pusztításai, a bombatámadások, a más célú felhasználá-

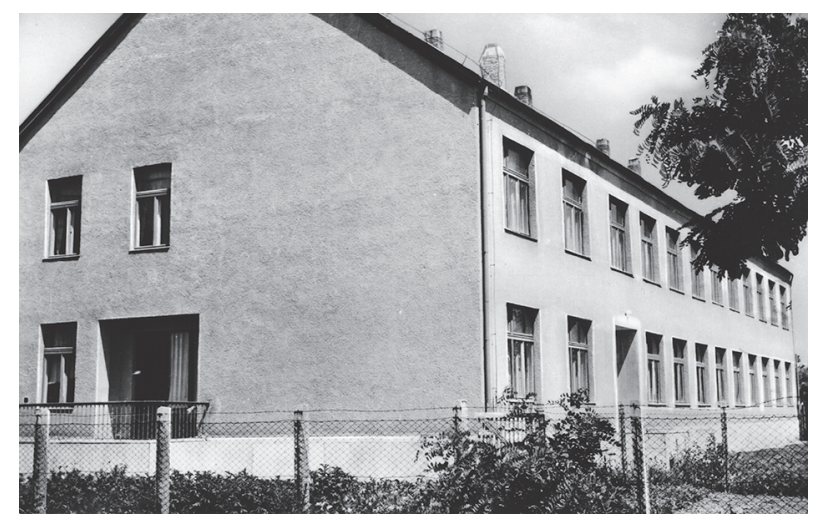

5. Reischl Péter típusterve (MOT. I. 3-8/59. szám) alapján: Kunhegyes, iskola, 1960. Szerencsi Képeslapgyüjtemény sok - hadikórház, katonai szálláshely ${ }^{70}$ - miatt az épülethiány 1945 után pontosan akkora probléma volt, mint a kezdetekkor.) Az állam felismerve az oktatás szükségességét és az ehhez kellő épületek hiányát, „,a rendelkezésre álló fedezet keretében mennél nagyobb számú objektum felállítás"-ára ${ }^{71}$ törekszik, ezért müszaki osztályával vagy egy erre alkalmas, szintén minisztériumi felügyelet alatt álló intézménnyel típusterveket készíttet, s ezeket az egész ország területén, de döntően inkább az elmaradottabb vidékeken felépítteti.

\section{Az iskolák típustervei}

Az iskolák típusterveiről nemcsak a - hellyel-közzel - évente kiadott típusterv-katalógusokból tájékozódhatunk. A típustervezéssel már a hatvanas években több publikáció foglalkozott, de az 1968-as iskolaépítési kutatás 4 kötetes tanulmánygyüjteménye is első kötetének legalább kétharmadát a témára fordítja. Sajnálatos módon a források viszonylagos bősége inkább hátráltatja a pontos kép kialakítását a teljes épületállományról, mivel a TTI kiadványainak $^{72}$ adatait érezhetően a propaganda támogatja, az Iskolakutatás csak a népszerúbb tervekkel foglalkozik, és bár a legrészletesebben sorolja fel, hogy hol épültek meg az adott tervek, a felsorolások adatai és az azokat követő számbeli összesítések időnként elírásgyanúsak. Nem sokkal célravezetőbbek a korabeli vagy azóta készült statisztikák sem, mert tapasztalatom szerint a korabelieket inkább a felfelé kerekítések, míg az 1989 utáni szövegeket ${ }^{73}$ - amelyek a szocializmus időszakához kritikusan állnak - gyakran a lekicsinylő adatértékelések jellemzik. Egészen egzakt számokkal való illusztrálás lehetősége nem lévén, a most következő fejezetben Kiss István és Jeney Lajos 1968-as iskolakutatásának összesítéseit vettem alapul, mert a téma megközelítésében az tűnt a legkiegyensúlyozottabbnak. Ráadásul számításaik a józanul megbecsülhető hibahatáron belül mozognak, így a megmutatkozó arányokon és nagyságrendeken nem változtatnak. A Kiss-Jeney-féle kutatás szerint míg 1950 és 1957 között évenként átlagosan 240 osztályterem épült, addig 1959 és 1965 között átlagosan 811, 1966 és 1968 között átlagosan 699 tanterem épült fel évente. ${ }^{74}$

Tanulmányuk alapján 1950 és 1968 között 16 féle iskolatípusterv készült. ${ }^{75}$ Ebből kettőt a Mezőterv (1951), hármat a Városterv (1952), egyet a Pécsi tervező vállalat, egyet pedig az időközben megszervezett Típustervező Intézet (pontosabban Reischl Péter és Ferenczy Béla, 1961) készített, a többi a KÖZTI rajzasztalain született. Főként Reischl Péter, illetve Kiss István jegyzi ezeket, de Bognár István, 


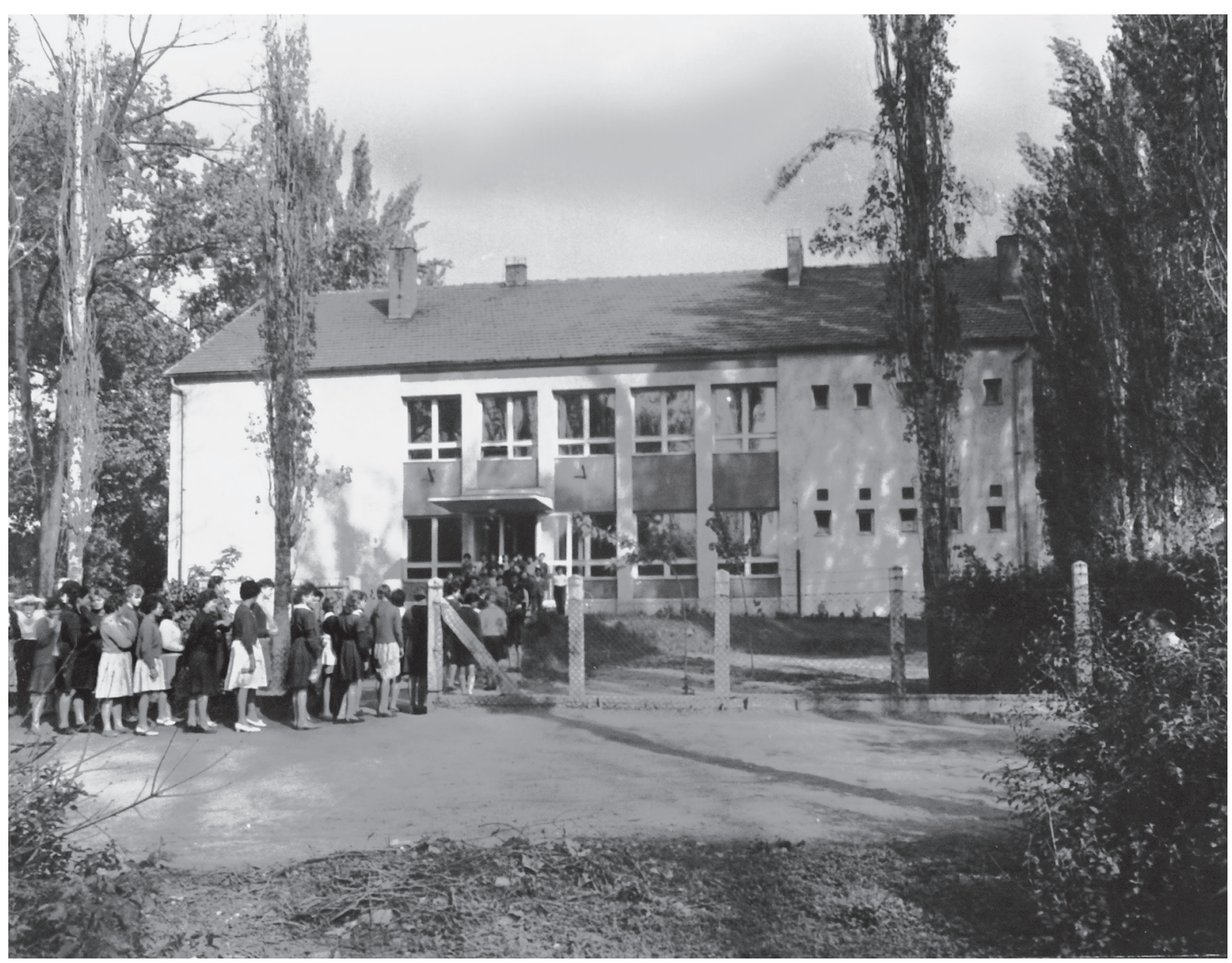

6. Kiss István típusterve (MOT. I. 3-18(19)/59. szám) alapján felépült iskola. KÖZTI Archívum, hely nélkül, évszám nélkül

Vass Tamás és Mueller Éva neve is a tervezők közt van. A tervek 1-12 tantermes általános iskolák tervei, illetve kettő közülük 8-16 tanulócsoportos gimnázium.

Az 1959-es tervek ${ }^{76}$ egy része falvakba készült, földszintes, közmű nélküli, nyeregtetős épület, téglány, vagy 4 tanterem esetén L alakú alaprajzzal, cserépkályhafütéssel, udvari kutas vízellátással. Némelyikhez melléképület is tartozik, amelyben árnyékszék, tüzelőraktár, illetve a szolgálati lakásban lakó tanár ellátását szolgáló ólak kaphattak helyet. Ezek tervezője Reischl Péter volt, a terveket pedig a KÖZTI dolgozta ki. 1960-1968 között az egy- és kéttantermes típus összesen 180 helyen (pl. Ágasegyháza, Kunszállás, Sajóivánka, Forráskút), a 4 osztálytermes 25 helyen (pl. Gyékényes, Kunfehértó, Páhi) épült fel. ${ }^{77}$ Másik részük ${ }^{78}$ szintén vidékre szánt, kétszintes, 4-8 tantermes iskolaépület zsibongóval, tanulószobával, természettudományi előadóval, melegítőkonyhával és egy kétszobás lakással. A Reischl Péter és Bognár István tervezte verzióból 1960 és 1968 között 79 épült meg (pl. Har- kány, Drávasztára, Makó, Bodrogolaszi). ${ }^{79}$ A Kiss István tervezte változatok két 6 méteres traktusból állnak, az emeletre széles, orsóterü kétkarú lépcső vezet. Az 1959-es változatban egy, az 1964-esben két tágas központi közlekedő tér - zsibongó - van. Az ő terveiből 72 helyen (pl. Öttevény, Pannonhalma, Csókakő) épült iskola. ${ }^{80}$

Reischl Péter két olyan iskolát is tervezett 1959ben, amely egy emeletes és egy földszintes szárnyból áll. Az emeletes részben vannak a tantermek, a földszintesben a tanári szobák és a szolgálati lakás. A tantermek négyzetes alaprajzúak, és az országban elsőként kétoldali megvilágításúak. ${ }^{81}$ Reischl másik 1959-es, Vass Tamással közösen tervezett nyolctantermes típusterve U alaprajzú, aránylag keskeny telekre, így akár belterületre is építhetô, és szükség esetén 8 tanteremből 12-re bővíthető. Tantermi, tornatermi és igazgatási szárnyból áll. A tervek mühelytermes és főzőkonyhás változatokban is elkészültek. Ezek a típustervek 121 helyen, 972 tanterem felépülését tették lehetôvé (pl. Kazincbarcika, Szentes, Kiskunfélegyháza, Mór). ${ }^{82}$ 


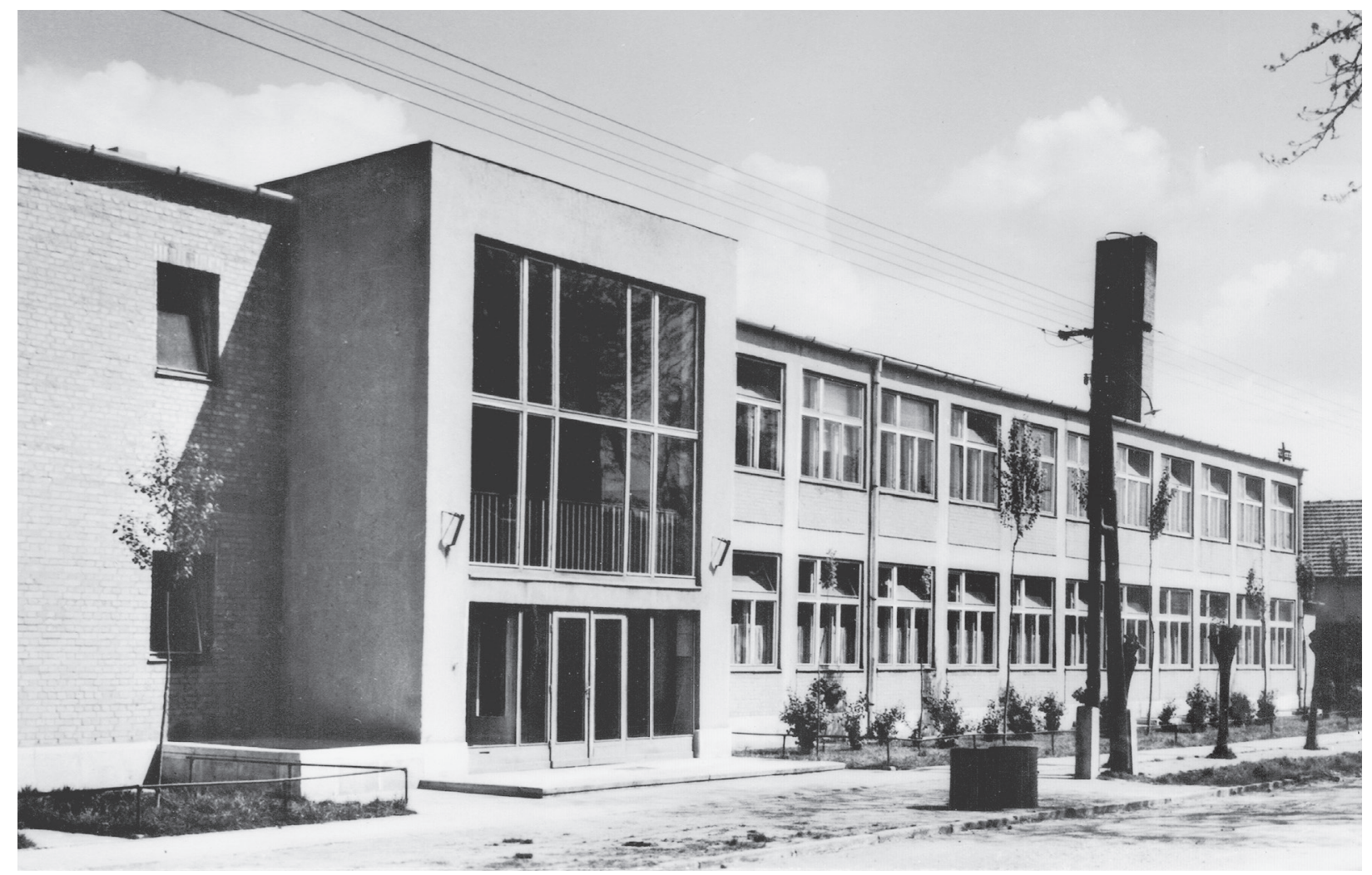

7. Reischl Péter típusterve [MOT. I. 3-16/59. (3-30/60) szám] alapján: Kiskunfélegyháza, iskola, 1962. Szerencsi Képeslapgyüjtemény

Kiss István rövid, tömör, egytömegü és kéttraktusos, emeletes épületeket is tervezett. A mindkét szinten zsibongós iskolák 126 helyen (pl. Fonyód, Balatonfüzfö, Bodroghalom, Solymár, Vaja) épültek meg. ${ }^{83}$ A hatvanas évek elejétől megjelentek a blokkos szekciókból flexibilisen felépíthető iskolák tervei. Tervezői Reischl Péter, Ferenczy Béla (TTI) és Mirgay László (KÖZTI) voltak. ${ }^{84}$ Ezeket 1968-ig 13 helyen, főleg nagyvárosokban (pl. Budapest, IX. Üllői úti lakótelep, Tatabánya-Újváros, Székesfehérvár-lakótelep, Szolnok) építették fel.

Mueller Éva az emeletes tantermi szárnyat acélszerkezetes üvegezett nyaktaggal kapcsolta a földszintes gazdasági és tornatermi szárnyhoz. ${ }^{85}$ Brjeska István típusterve kétemeletes, lapostetős, U alaprajzú épület, hozzácsatlakozó földszintes kazánházzal és tornateremmel. Bővítés esetén az U nyitott része beépíthető, és díszudvar kialakítása lehetséges. ${ }^{86}$

Köves Emil 1961-es 12 tantermes típusterve lapos tetős, préselt kavicsfedésű, háromszintes épület, aszimmetrikus elrendezésű homlokzattal. A szintenként négytantermes szárny két végéhez ellentétes irányokból csatlakozik a konyha-étterem és szolgálati lakás szárnya, illetve a tornatermet és mühelyeket magában foglaló épületrész. $\mathrm{Az}$ épület különlegessége nemcsak a homlokzat szélére húzott és nagyméretü ablakokkal megnyi- tott lépcsőház, hanem a tantermek megvilágítása is. A homlokzaton vízszintesen három ablaksáv fut végig, amely csak a termek osztásánál szakad meg. Az egyes termek keskeny ablaksávjai bal oldalukon egy-egy nagyobb ablakkal bővülnek. Az alaprajzból az is kiderül, hogy a nagyobb ablakfelületek a termek bejáratával szemben vannak, vagyis a tanári asztal, tábla megvilágításában kapnak szerepet. Ebből az épületből 1965-ben négyet, 1966-ban kettőt (Szentlőrinc, Zalaegerszeg) építettek fel. ${ }^{87}$

Az 1960-as katalógus típustervein a tantermek 51-52 négyzetméteresek, belmagasságuk kicsivel 3 méter fölött van. ${ }^{88}$ Mindenütt van szélfogó, a folyosók és a tanári szobák is megfelelő méretűek. Ezzel lényegében teljesítik a korábban ismertetett egészségügyi és építési előírásokat. Az 1959-es tervek javarészt egyszerü tömegúek. A tantermek és tanári, kiszolgáló helyiségek, illetve a szolgálati lakás jól elkülönülten helyezkednek el. A homlokzatokat részben a funkció alakítja: a tantermek több elemből álló és nagyobb méretü ablakcsoportjai, a tanárik, tanulószobák kisebb számú és méretű ablakai, illetve a zsibongó, a lépcsőház összetett ablakfelületei többnyire aszimmetrikussá teszik a homlokzatot. Az ablakok ritmusa mellett a rizalitok, melyek a földszinten a szélfogót, az emeleten a zsibongó kiteresedését rejtik, a hangsúlyos, helyenként haránt irányú lábak- 

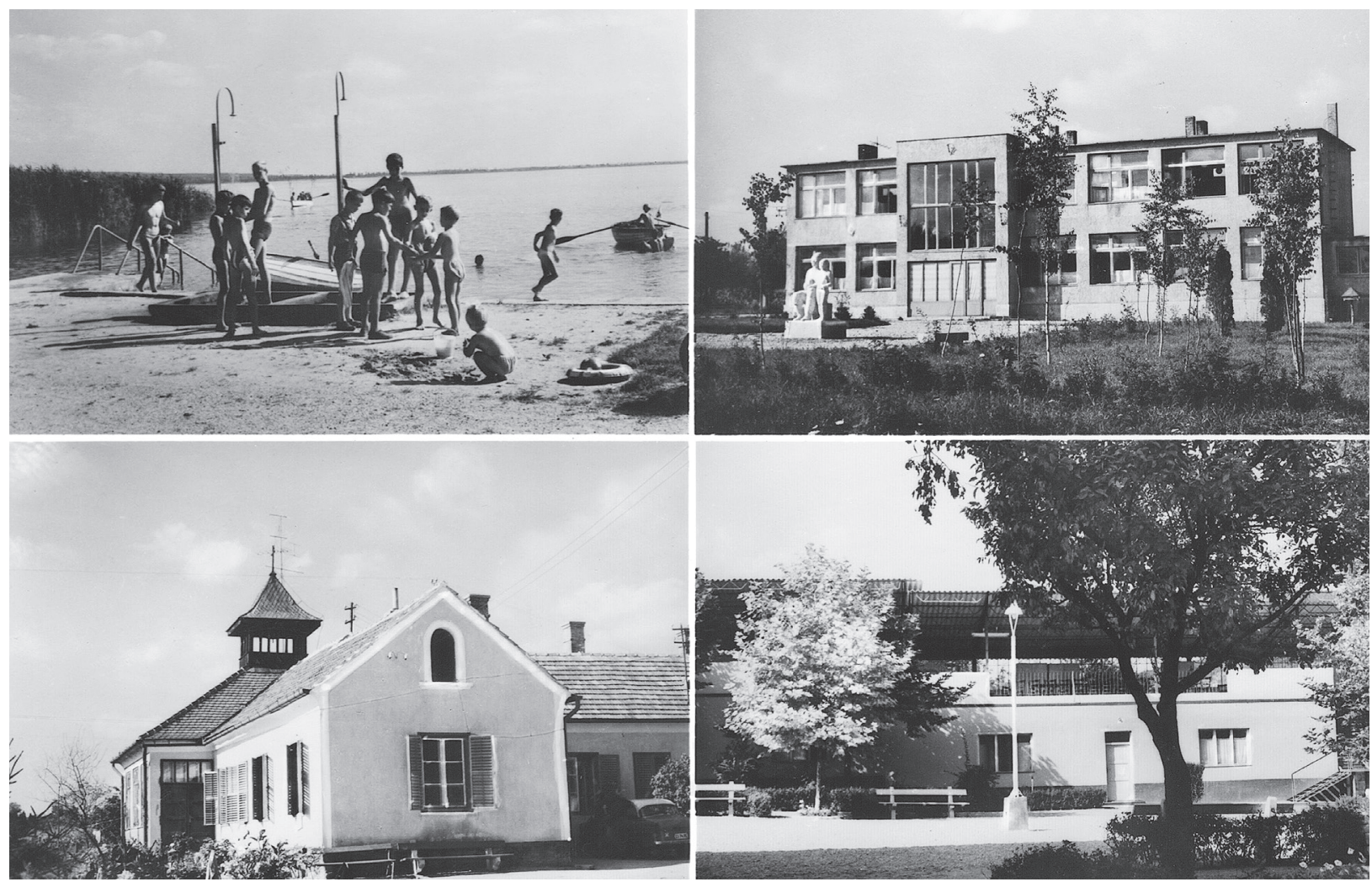

8. Reischl Péter típusterve (MOT. I. 3-12/59. szám) alapján: Gyékényes, iskola. Szerencsi Képeslapgyüjtemény

ra támaszkodó, nagy kiülésű előtetők is azt mutatják, ${ }^{89}$ hogy ezek az épülettervek sem nélkülözik az építészi invenciót, és nem a tervezői igénytelenség vagy építészi ötletesség hiánya okozza azt, hogy ezek az épületek mai szemmel nézve észrevétlenek.

\section{Az egyedi tervezésü iskolák}

A fenti politikai-törvényi háttér ismeretében felmerülhetne a kérdés, hogy hogyan is volt lehetőség egyedi tervek kidolgozására, amikor előbb csak ajánlásként, majd egyre nyomatékosabb törvényi megfogalmazásban a típustervezés kizárólagossága volt az irányadó. Márpedig nemcsak tudomásunk szerint volt magas az egyedi tervek alapján megépült iskolák száma, hanem az 1968-as felmérés is ezt erősíti meg. Eszerint ugyanis a korszak épületállományában „,az egyedi tervek igen nagy száma [jellemző, hisz ez] az 1960-tól a megépített osztálytermek csaknem $25 \%$-a". ${ }^{90}$ A miért megválaszolása néhány épület ismertetése után válik lehetségessé.

A korszak iskolatervező mestere, KismartyLechner Kamill ${ }^{11}$ két iskolaépületet tervezett Szikszóra. Az egyik egyszerü tömegü, a másik nyolctantermes összetett tömegü épület. Mindkettő homlokzatai terméskő borításúak. Az utóbbiban a folyosók helyett a központi, oldalvilágítású, kertre néző térből nyílnak az osztálytermek. Ezt a teret ő nevezte el zsibongónak, ami később általános fogalommá vált. ${ }^{92}$

Ô tervezte 1955-1957-ben ${ }^{93}$ a soroksári Sodronyos utcai nyolctantermes iskolát. Az épület két tömbből áll, amit folyosó köt össze. A kétszintes fóépület földszintjén vannak a tantermek és a szolgálati lakás, az emeleten a természettudományi előadó, a szertárak, a konyhaüzem, az étkezőnek is használt tanulószoba, valamint az igazgatási és ifjúsági helyiségek. Középső traktusában az épület teljes szélességében kétszintes magasságú központi, ún. csarnokzsibongó található, amelyhez a második szint közlekedői galériaszerúen kapcsolódnak. Alagsorában a kazánház, a raktárak, a széntároló, a politechnikai mühelyek kaptak helyet. Ezek megvilágítását a lejtős terep kihasználása tette lehetővé. Földszintes tömbjében a tornaterem, a tornaszertár, az öltözők és zuhanyzók és az orvosi szobák vannak. Az összekötő folyosó és a földszinti helyiségek is lépcsőházi pihenőről nyílnak.

A központi csarnokzsibongó a bütüfalakon $6 \times 7$ méter méretű ablakfallal zárul, mely mögött télikert van. A korabeli szakirodalom azt emeli ki, hogy a „terv a kétszintes középzsibongós alaprajzi 


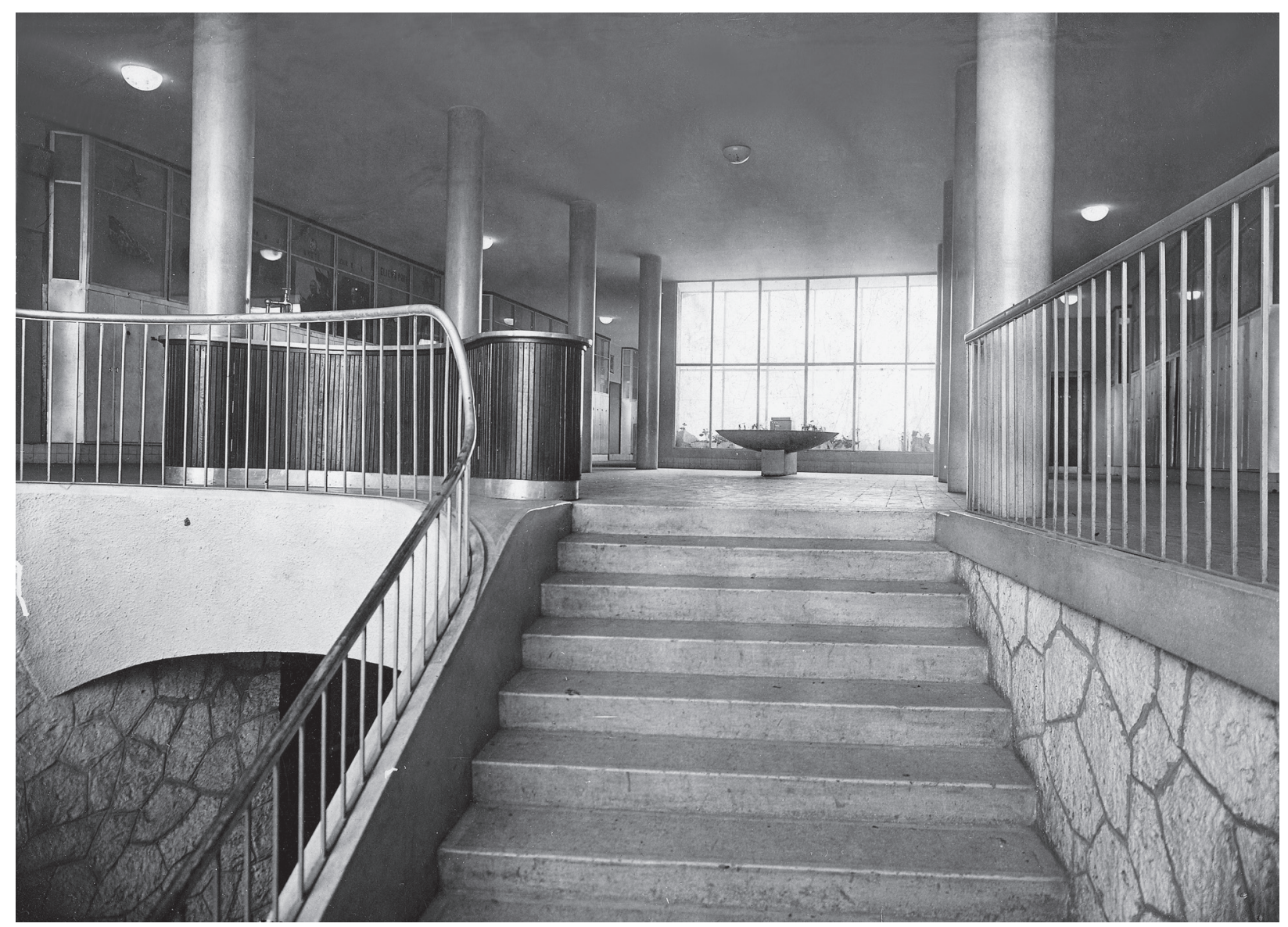

9. Kismarty-Lechner Kamill: Szikszó, általános iskola, 1948. Kismarty-Lechner-hagyaték, magántulajdon

elrendezés jellemző példája, hagyományos, egyoldali megvilágítású tantermekkel. Térkialakítás és térkapcsolás szempontjából az építés időpontjában egyedülálló kezdeményezés volt." ${ }^{94}$ Az épületet lényegtelen változtatásokkal a budapesti Kőbányai úton is megépítették. Ilyen különbségek, hogy a Kőbányai útiban a központi zsibongó fala vakolt, míg a Sodronyos útiban klinkerburkolatos.

Bár Kismarty 1987-es cikkében úgy fogalmaz, hogy „ez volt az első csarnokzsibongós [kiemelés az eredetiben, L. E.] iskola nemzetközi viszonylatban is", ezt nem lehet egyértelmúen megerősíteni. Ake Lindquist 1948-ban tervezett, Björkshagenben (Stockholm) található iskolája ugyanezzel a megoldással él. A hosszú, kétszintes, klinkerborítású falak határolta központi tér, mely a bütükön nyíló hatalmas ablakokból kapja a fényt, az egyik hosszanti falon futó fémkorlátos erkélyről megközelíthető emeleti tantermekkel, ${ }^{95}$ látványosan hasonló megoldás.

Kismarty-Lechner következő újítása az oldalzsibongós, úszólépcsőházas megoldás volt, melynek első példája Tatabánya-Kertvárosban épült fel 1959-1960-ban. A bánhidai hegyekre néző, menynyezettől padlóig érő ablakok előtt egy sajátos designmegoldás: a korlátradiátor húzódik végig. A folyosó bütüfalai a Sodronyos utcai iskolához hasonlóan klinkerborításúak, szabálytalanul elhelyezett üres táblákkal, amiket Tatabányán Majoros János és Majoros Hédi kerámiaképei töltenek ki. Ez a felületképzés ugyancsak gyakori megoldás volt a nemzetközi iskolaépítészetben is. ${ }^{96}$

A teljes oldalfalas megvilágítás tantermi verzióját is Kismarty valósította meg a Szárcsa utcai iskolájánál. ${ }^{97}$ Ezt az osztálytermek ferde síkú, teljes felületükben üvegezett, visszaugratott homlokfalaival oldotta meg, amit az egyes szintek lépcsőzetes hátratolása tett lehetővé. A belső területeken csökkentett $(2,7 \mathrm{~m})$ belmagasságúak a 8 méter mélységü osztálytermek. A négyszintes épület földszintjén van a tágas elő́csarnok, az igazgatási helyiségek, a tanuló-étkező, a főzőkonyha és a szolgálati lakás. A második szinten öt osztályterem van, öt méter széles zsibongóval. A harmadik szinten található három osztályterem, a természettudományi előadó és annak előkészítői és a három méter széles folyosó. Alagsorában vannak a politechnikai mühelyek és a fütési helyiségek. A lépcsőházi orsótér üvegtéglából falazott. A tantermek délkeleti tájolá- 


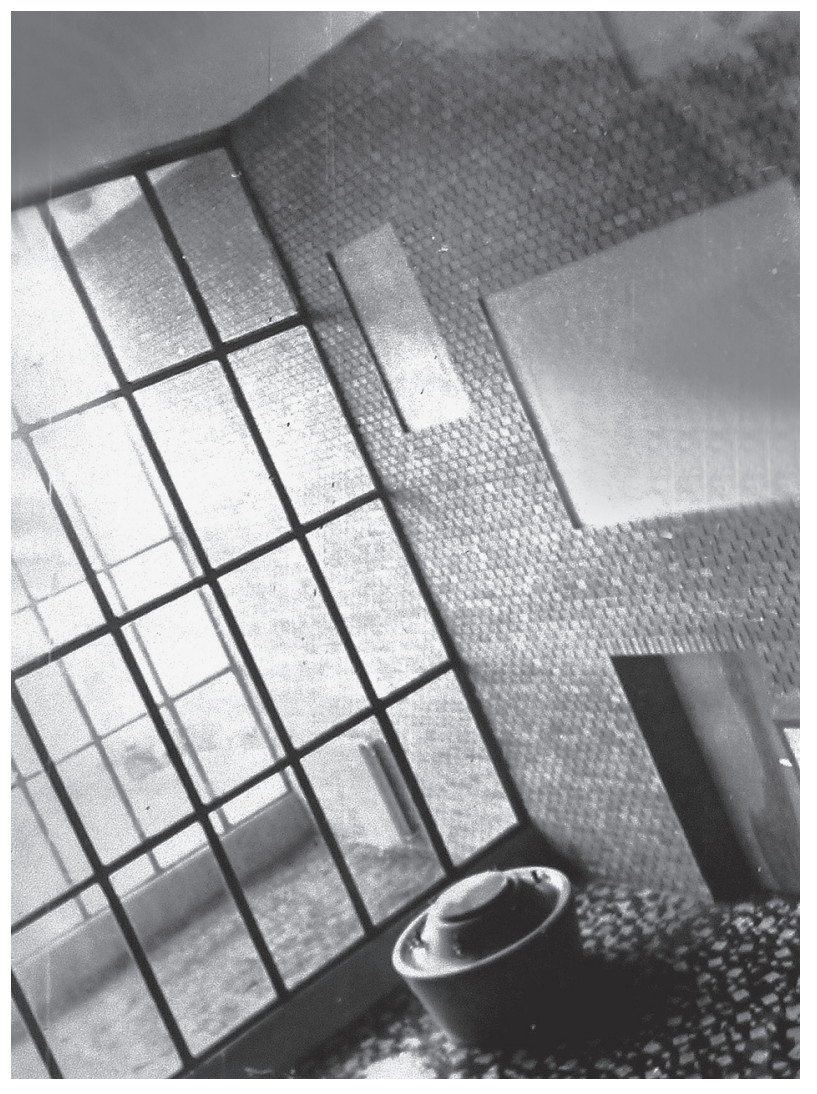

10. Kismarty-Lechner Kamill:

Budapest, Sodronyos út 28., általános iskola, 1955-1958. Kismarty-Lechner-hagyaték, magántulajdon

súak. A földszinti és emeleti zsibongó nagyméretü, így alkalmas az iskolai ünnepségek megtartására is. ${ }^{98} \mathrm{Az}$ épület összetett tömegét az egyes tömbök félnyeregtetős lefedése hangsúlyozza. Mind az a megoldás, hogy a benapozást, a fény beesését a lejtős lefedéssel éri el, mind pedig, hogy a különböző funkciójú épületrészek ferde tetőit egymást metszően forgatta össze, ezzel érve el a tömegek dinamikáját, 1962-ben már Magyarországon sem volt újdonság, hiszen Zalaváry Lajos is ezt alkalmazta 1952-ben feldebrői iskoláján.

1960-ban készült Kismarty-Lechner átlós bilaterális világítási rendszerü iskolaterve, amelynél a tantermek hangfogó előtereken keresztül csatlakoznak a tanításra is alkalmas zsibongótérhez. Ez az elképzelés több esetben volt programterv, de „kiviteli tervvé csak egy évtized múlva válhatott, pedig rendszere mindössze kétféle födémpanelon alapult". ${ }^{99}$ 1963-1965-ben megvalósult Budapesten az Alsóerdősori iskolája. Itt a kétszintes oldalzsibongóból haránt irányban nyílnak az osztálytermek, és így a zsibongón keresztül épp megfelelő szögü másodlagos bevilágítást kapnak. Az épület teljes homlokzati üvegfallal és a jobb telekkihasználás érdekében lábakra állítva készült.

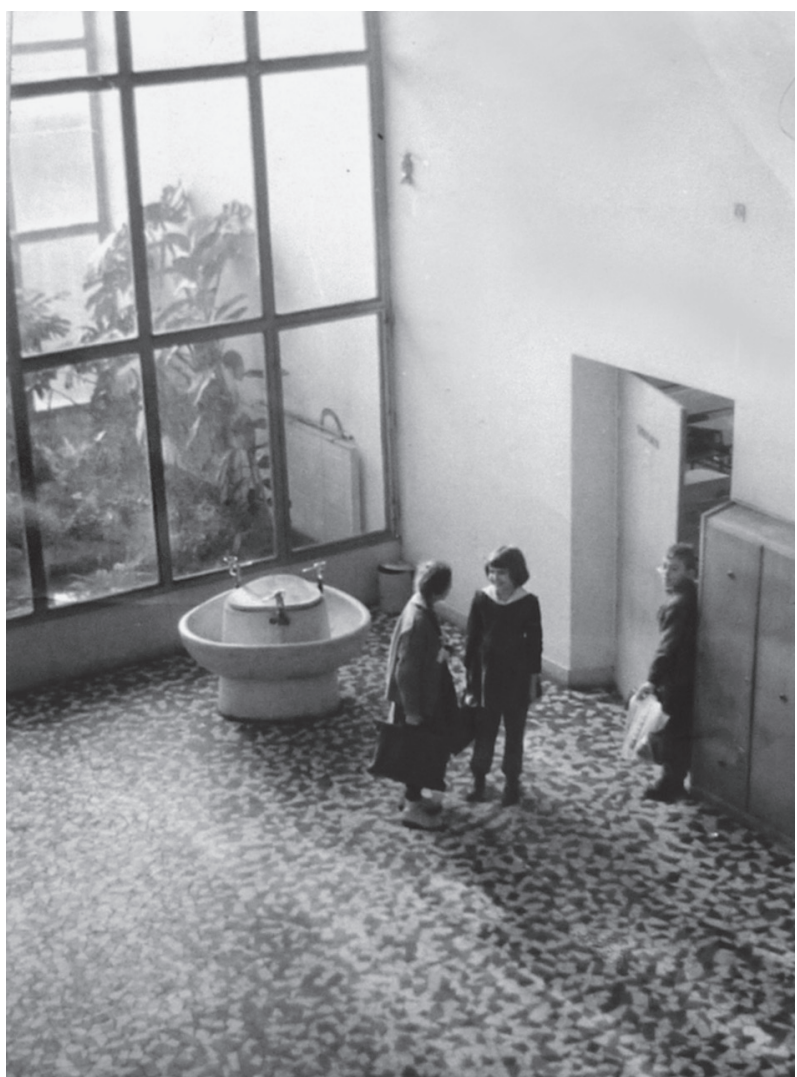

11. Kismarty-Lechner Kamill:

Budapest, Kóbányai út 38., általános iskola, 1957.

Kismarty-Lechner-hagyaték, magántulajdon

A KÖZTI másik nagy iskolaépítője, Reischl Péter nem csak típustervekkel dolgozott, bár Ybl-díját részben ezekre kapta. ${ }^{100} \mathrm{~A}$ másik érdeme azonban a Fóti Gyermekváros 16 osztálytermes általános iskolája volt. Annak tervezése és építése egy időben, 1958-1960-ban zajlott. ${ }^{101}$ A lejtôs terepadottságok figyelembevételével megtervezett iskola három különböző funkciójú tömegből áll. A hosszan elnyúló, kétszintes fóépületben 5 méter széles központi zsibongó és a négy lépcsőházból nyíló két-két, kétoldali megvilágítású tanterem található. A téglaborítású központi tömeghez nyaktaggal kapcsolódik a földszintes, középfolyosós igazgatási szárny, benne az igazgatási helyiségekkel, a politechnikai műhelyekkel, a természettudományi előadóteremmel, a WCcsoporttal. A trapéz alaprajzú nyaktag rejti a bejáratot, felette hosszan kinyúló, legyező alakú előtető. A másik földszintes szárnyban van a $10 \times 20$ méter alapterületü tornaterem, a mosdó és zuhanyzó, a szertárak, a fütési helyiségek és a szellőző gépház. ${ }^{102}$

A másik, típustervezésben is gyakorlott és szintén Ybl-díjas ${ }^{103}$ építész, Kiss István tervezte a kaposvári nyolc osztálytermes általános iskolát 1959-ben. ${ }^{104}$ A terephez illeszkedő, nyújtott tömegü, kétszintes, harántfalas szerkezeti rendszerü 


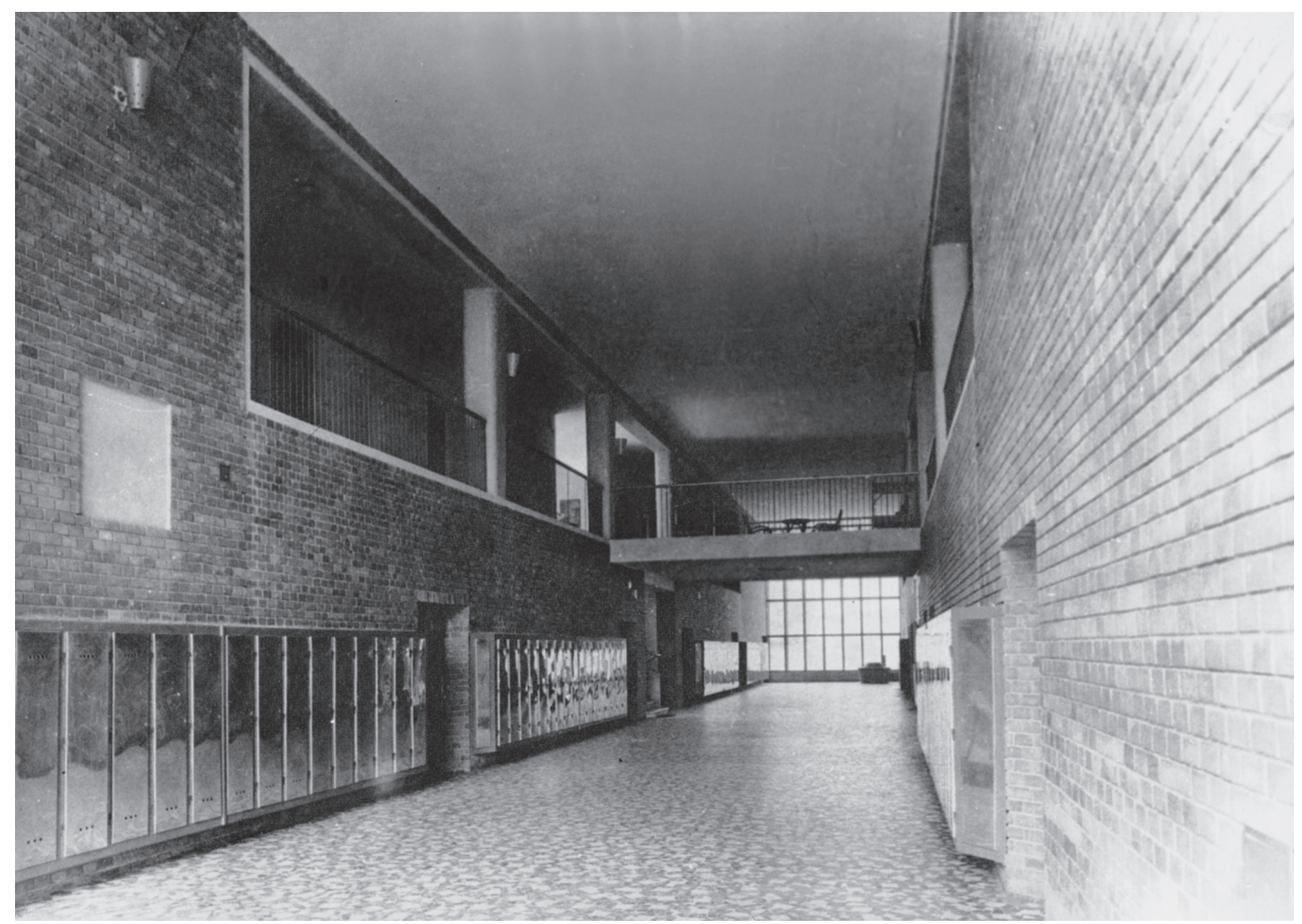

12. Kismarty-Lechner Kamill: Budapest, Sodronyos út 28., általános iskola. 1955-1958.

Kismarty-Lechner-hagyaték, magántulajdon

épület második szintjén oldalfolyosós kapcsolattal sorakoznak a kétoldali megvilágítású tantermek. Másodvilágításukat az oldalfolyosó fölött a tantermek ferde síkú emelt mennyezete teszi lehetővé. Földszintjén a bejárati előtér, az igazgatási helyiségek, a politechnikai műhelyek, a külső bejáratú szolgálati lakás és légoltalmi óvóhely található. Ez

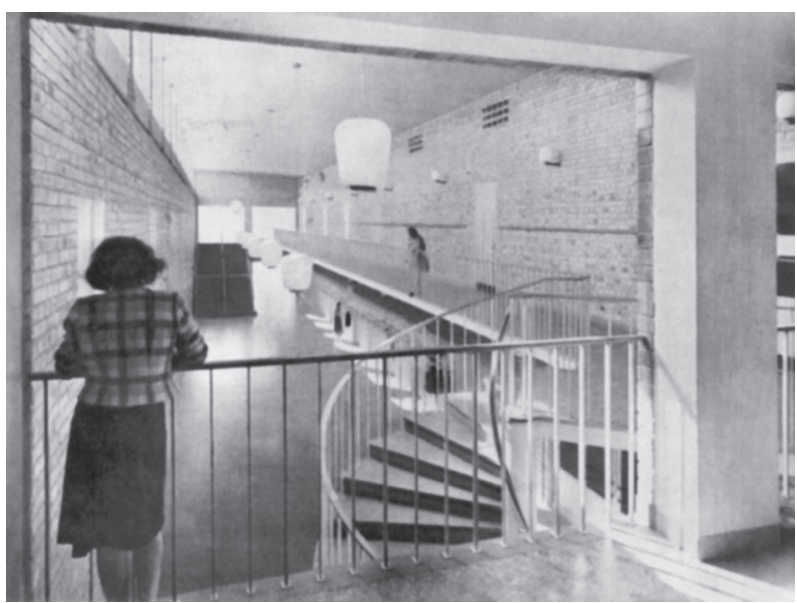

13. Ake Lindquist: Björkshagen (Stockholm), iskola, 1948. Brödner-Kroeker 1951, 87. nyomán az épületterv alapkoncepciójában az első kezdeményezés volt a kétszintes épületben elhelyezett kétoldali megvilágítású osztálytermek és az oldalfolyosós rendszerű közlekedőterek kapcsolatának megoldására. ${ }^{105}$

Budakeszi nyolc osztálytermes általános iskolája 1960-ban ${ }^{106}$ készült, és tervezője, Brjeska István 1961-ben kapott érte Ybl-díjat. ${ }^{107}$ A lejtős terepen álló, L alaprajzú, kétszintes épületnek emelt szintű udvarai vannak. Hosszanti szárnyában osztálytermek, a rövidebben tornaterem és annak járulékos helyiségei találhatók. A részben nyitott előudvar kapcsolódik az előcsarnokhoz, ahonnan a földszinti osztálytermek, az igazgatási helyiségek, az úttörőszoba, az étkezőnek is használt tanulószoba, a főzőkonyha és az utcáról is megközelíthető szolgálati lakás nyílik. Az emeleten nyolc osztályterem, ebből kettő és a természettudományi előadóterem a terepviszonyok miatt fél szinttel magasabban van. Az iskola jellegzetessége a $6,4 \times 8$ méter alapterületü osztálytermek ferde mennyezete, lépcsős elhelyezésű két ablaksorral, ami a jó megvilágítást szolgálja. Ennek előképe Arne Jacobsen 1957-ben felépült iskolája. 


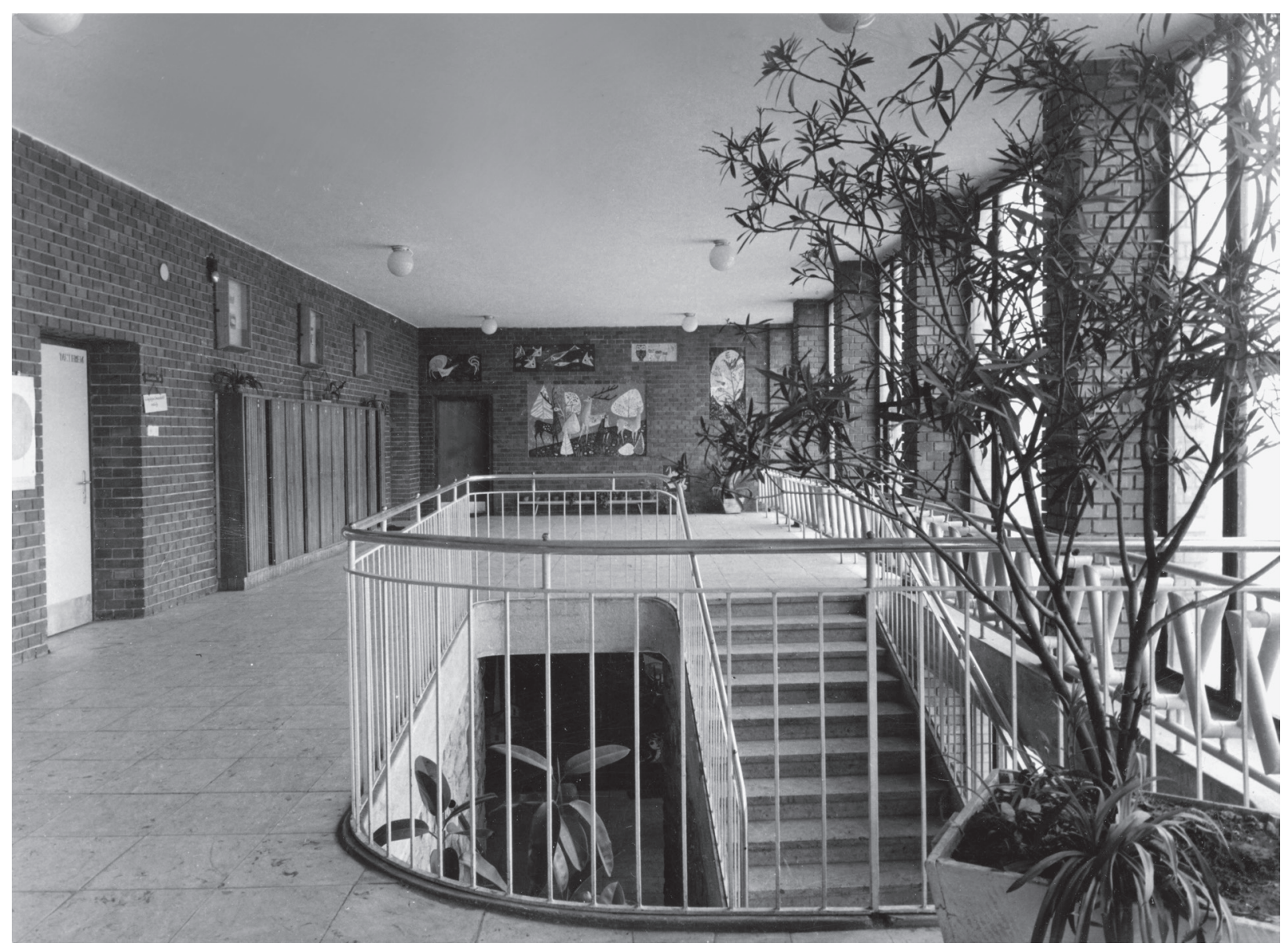

14. Tatabánya-Kertváros, általános iskola, 1959-1960. KÖZTI Archívum

Ezt a fajta egyoldali, kétsoros tantermi megvilágítási rendszert alkalmazza Szrogh György is a mogyoródi és dunavarsányi hattantermes általános iskoláknál. ${ }^{108}$ A mogyoródi általános iskola 1961ben ${ }^{109}$ kissé lejtôs terepen épült hat tanteremmel, egy előadóteremmel, három szertárral, egy tanulóés egy úttörőszobával, egy politechnikai mủhellyel, tanári szobákkal és a zsibongó előcsarnokkal. ${ }^{110}$

Zalaváry Lajos a budapesti Csepel-Csillagtelep 24 tantermes iskoláját 1956-1957-ben tervezte, kivitelezésére 1957-1959-ben került sor. ${ }^{111}$ Az 5000 fős lakótelep központjában lévő iskola külön szárnyában tanultak a fiúk és a lányok. A tornaterem és a közösségi helyiségek is szeparáltak voltak, csak a konyhaüzem volt közös. Az épület kétemeletes, a földszinten vannak a tanári szobák, emeletenként pedig a 6-6, 42 fös tanterem. Az U alakú épület teljes földszintjét a közösségi helyiségek foglalják el. A folyosó-zsibongó szélességi méretét a lépcsőház újszerü megoldásával az összalapterület emelkedése nélkül a korábbi gyakorlatban használt 2,40 méterről 6 méterre növelték. Az így kialakult nagy fesztávolságok nagy bevilágító felületeket is jelentettek, és indokolttá tették a vasbeton pillérváz alkalmazását. További technikai kihívást jelentett a folyosó légterébe helyezett egykarú lépcső szerkezete. A 9 méteres lépcsőkarhossz csak úgy volt megoldható, ha a lépcsőkart kiváltó gerendát vascsövekkel a fölötte levő födémre függesztették fel.

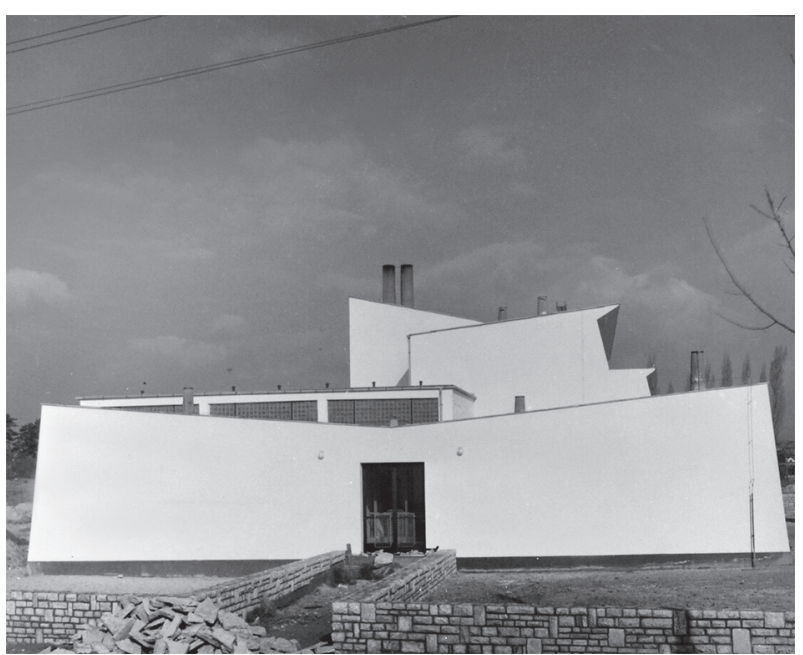

15. Kismarty-Lechner Kamill: Csepel, Szárcsa utca 9-11., nyolcosztályos általános iskola, 1960. KÖZTI Archívum 


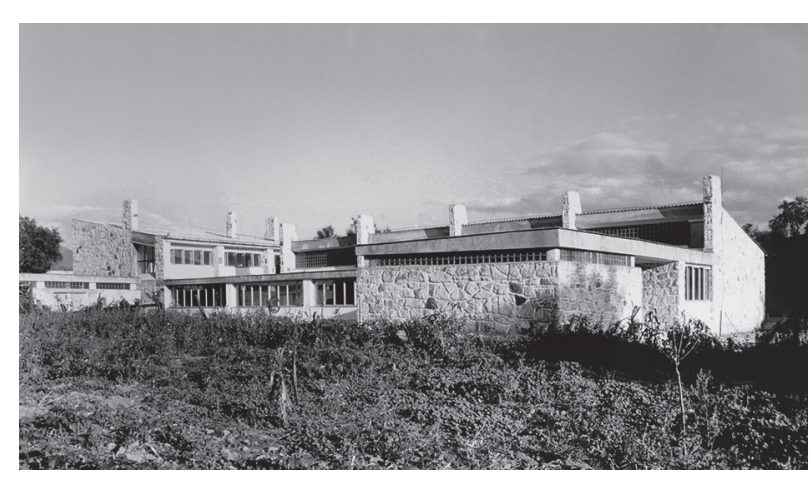

16. Zalaváry Lajos: Feldebrő, általános iskola, 1952. KÖZTI Archívum

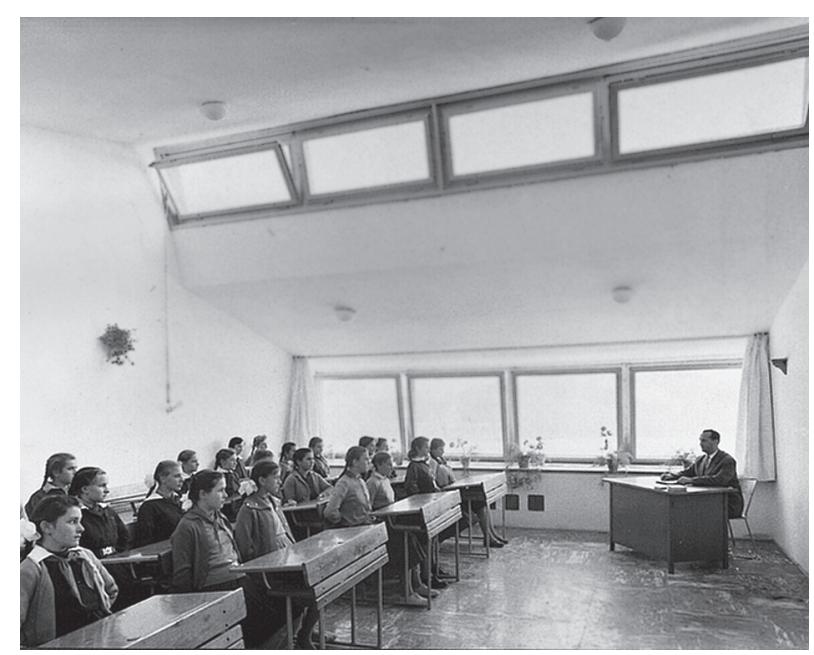

17. Szrogh György: Mogyoród, általános iskola, 1961. KÖZTI Archívum

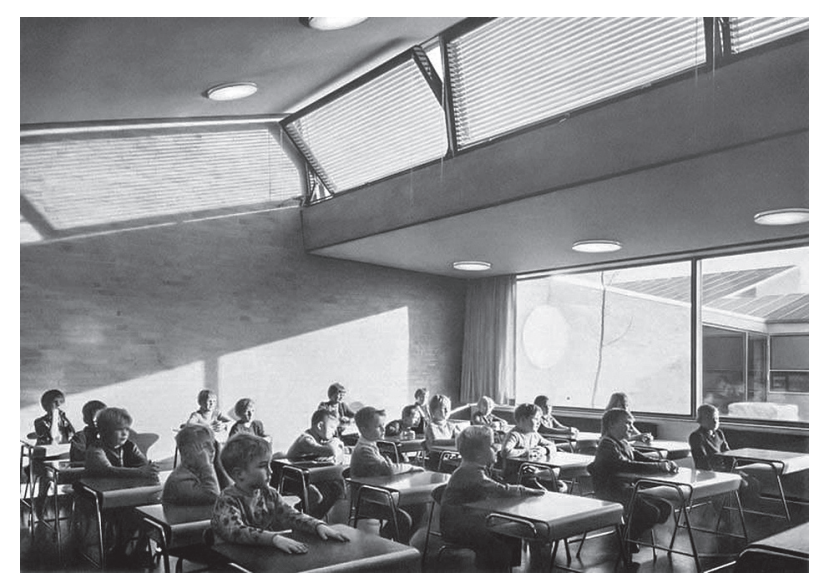

18. Arne Jacobsen: Gentofte (Koppenhága),

Munkegårdsskole, 1957. http://notnew.tumblr.com/ post/23285771024/location-soborg-denmark-architect-arne

A folyosóról előnyösen megmutatkozó, könnyű megjelenésű lépcsőfokokat kétoldalt tömör pofafal fogta össze. Az egész szerkezet monolit, helyszínen zsaluzott vasbeton szerkezet műkő felhordással.

Dunaújváros 32 tantermes általános iskoláját B. Császár Ildikó 1955-ben kezdte tervezni, és 1959- 1960-ban adták át. ${ }^{112}$ Ez volt az egyik legnagyobb osztályteremszámmal megépült iskola. A 32 tanterem két 16 tantermes iskola összeépítését jelentette közös konyhával, éttermi és igazgatói helyiségekkel. Az épület négyszintes, főtömege szimmetrikus. Homlokzata tengelyében nyílik a trapéz alapú hasábokra rövid lábbakkal támaszkodó, így lebegni látszó beton előtetővel megoldott bejárat. Az ennek két oldalán lévő, egyenként $21 \mathrm{~m}^{2}$ felületü relief Laborcz Ferenc munkája. Az épület homlokzatához nyaktaggal kapcsolódik a tornatermek két kubusa, melyek antracitszínú csempeborítású falaikkal és haránt üveghomlokzataikkal impozánsan hatnak. Az étterembe Kovács Margit metlachira égetett kerámiája (János vitéz), a játszótérre Garami László és Kiss András haraszti kőből készült állatfigurás ivókútjai kerültek.

Mányoky László egri, a Trinitárius út - Bartók Béla tér sarkán álló nyolctantermes általános iskolájának tervei 1958-ra kelteztethetőek, felépítésére 1960-ban került sor. ${ }^{113}$ A hatásos megjelenésű iskola homlokzata aszimmetrikus elrendezésű. Különlegessége a bejárati rizalit, mely $\mathrm{V}$ alakú betontartókon áll, tömör homlokfalát plasztika borítja (szobrász: Vilt Tibor), oldalain pedig két szinten ablakok törik át. Megkoronázását, a homorú, íves betonfödémet karcsú ablaksor tartja. ${ }^{114}$

Gyöngyös Vásártéri lakótelepén található nyolc osztálytermes általános iskoláját Hofer Miklós jegyzi 1959-ből. ${ }^{115} \mathrm{Az}$ épület kialakítása megvalósításának hármas ütemezéséhez igazodik. Főtömege háromszintes, az emeleten tantermek, földszintjén igazgatási helyiségek, könyvtár, szertár, WC csoportok és szolgálati lakás találhatók. Az utcával párhuzamos, hosszanti tengelye észak-déli, az erre merőleges tantermi és tornatermi szárnyak keletnyugati elrendezésűek. A főbejárat az előcsarnokba vezet, ahonnan a folyosók lépcsőházaira van füzve a második és harmadik szinten elhelyezett 4-4, kétoldali megvilágítású, 6,4×7,8 méter alapterületü osztályterem. A földszinti WC-csoporton kívül a lépcsőházi pihenőkön is vannak mellékhelyiség-csoportok. Az udvari oldal felé néz a természettudományi előadó a szertárakkal, az úttörőszoba és a tornaszertár. Ezt a szárnyat zárja le a $10 \times 20$ méteres tornatermi tömb. A Kiss-Jeney-féle kutatás kiemeli, hogy „,az épület jellegzetes példája a kétoldali megvilágítású, tantermi rendszerek háromszintes megoldásának, és ezen a téren az első kezdeményezés volt". ${ }^{116}$ A tantermek nagyméretü felnyitással, termenként $\mathrm{kb} .21 \mathrm{~m}^{2}$ ablakfelülettel készültek, billenő alumíniumablakokkal. A tantermek méretét a harántfalas, illetve harántpilléres, 6 méter fesztávú, egyszerűen megépíthető szerkezet igénye szabta meg. ${ }^{117}$ A fenti épületek gyakori 
megoldása a tantermek kétoldali megvilágítására törekvés, amelyben szerepet játszhatott az is, hogy az iskolákban váltott rendszerben, délelőtt és délután is folyt oktatás, és így lehetett optimalizálni a délutáni benapozást is.

Ezeknek az épületeknek a paramétereit összevetve az építési előírásokkal azt találjuk, hogy a hosszanti elrendezésű tantermek $6 \times 9$ méteresek, a haránt elrendezésűek 6,4×7,8-8 méteresek. A bejárat előtetővel, szélfogóval és előcsarnokkal ellátott, és a folyosók, lépcsőházak is mindenütt nagy hangsúlyt kapnak. Meglepő azonban, hogy vannak esetek, amikor az újítások az építésügyi szabályok figyelmen kívül hagyását okozzák. Ilyenek például a mennyezettől a földig lefutó ablakok, hisz az elöírások szerint az ablakoknak a földtől számítva 0,8 méter magasan kell kezdődniük. Praktikusan az üveg törékenységével és a gyerekek szertelen térhasználatával függhet össze ez a rendelkezés, amit egyik megszegője, Kismarty-Lechner Kamill egy, a folyosó teljes hoszszában végighúzódó, szélesen kígyózó radiátorsáv-

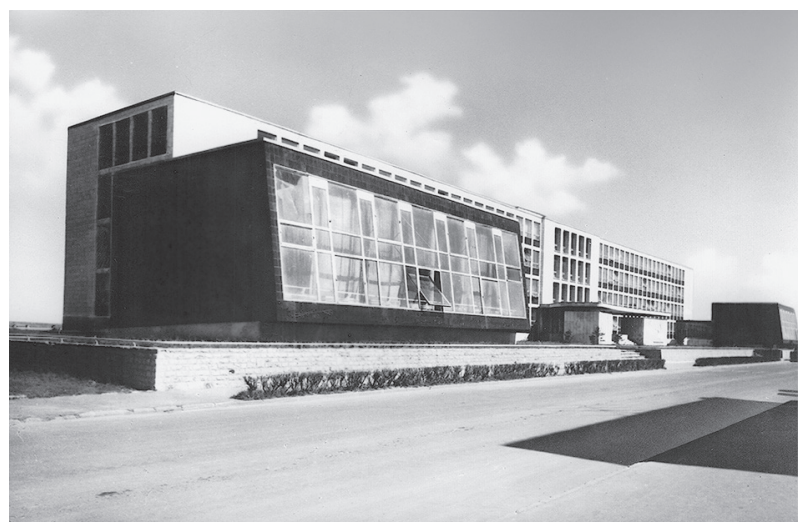

19. B. Császár Ildikó: Dunaújváros, általános iskola, 1959. Szerencsi Képeslapgyüjtemény

val véd ki. Nagyobb probléma, hogy több helyütt a megengedettnél kisebb lett a belmagasság a fölső megvilágítások érdekében alkalmazott ferde födémkialakítások miatt. Például Kismarty Szárcsa utcai iskolájában helyenként $270 \mathrm{~cm}$-re csökkent a kötelező 3,2 méteres belmagasság.

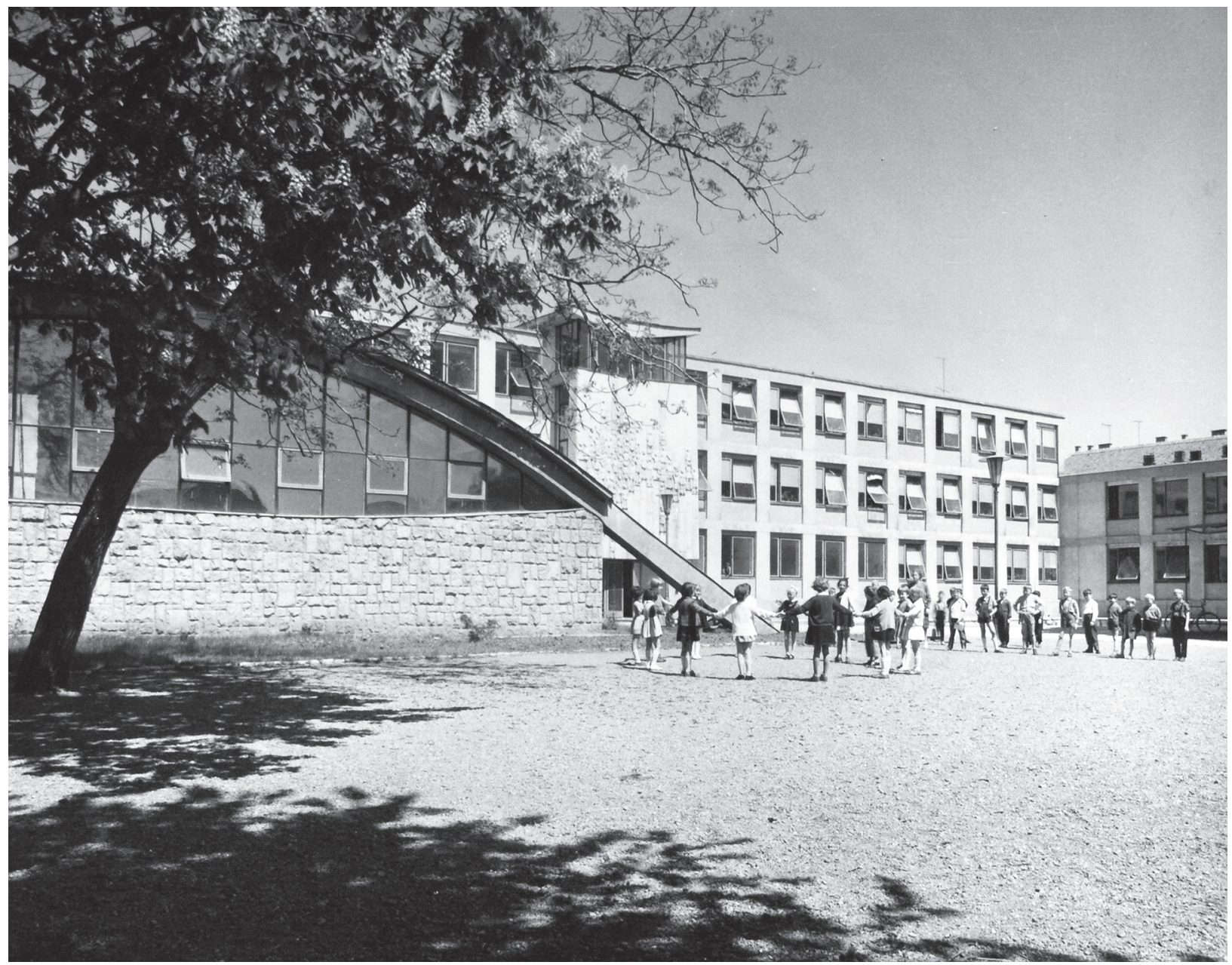

20. Mányoky László: Eger, nyolctantermes iskola, 1958-1960. KÖZTI Archívum 
Típus- versus egyedi tervek

Az előző fejezet elején feltett kérdésre, vagyis, hogy miként is épülhetett egyedi tervezéssel iskolaépület, ha már az ötvenes évek elejétől a típustervezést „javasolta” az építésirányítás, könnyű lenne a törvénykezés megengedte kiskapuval válaszolni. De nemcsak könnyü lenne ez a válasz, hanem félrevezető is. Hiszen ha megnézzük, a korábbi, 1958-as rendelkezés, noha „csak” kormányhatározat volt, a Beruházási Bank hitelmegvonásával fenyegette meg a típusterv megléte mellett újat készíttető állami beruházókat. Eszerint tehát 1958 és 1964 között egyáltalán nem épülhetett volna egyedi terv alapján iskola. Viszont láthattuk: ez nemcsak hogy előfordult, hanem viszonylag nagy számban meg is történt. Sőt, valójában éppen az 1964-es év jelent cezúrát, és csak azután csökken jelentősen az új iskolatervezések száma. Ez a határvonal a KÖZTI épületanyagának vizsgálatakor is szembetűnő. Adattáruk tanúsága szerint ugyanis ekkorra, az ötvenes évek végére és a hatvanas évek elejére tehetőek a jelentősebb iskolaépítések: 1956-1958: Mogyoród, Szrogh György; 1958: Újmohács, Mányoky László; 1958-1971: Budapest, Soroksár, Sodronyos utca; 1958: Szikszó és 1959: Tatabánya, KismartyLechner Kamill; 1959: Eger, Mányoky László; 1960: Gyöngyös, Hofer Miklós és Fót, Reischl Péter; 1962: Budapest, Csepel, Szárcsa utca, Kismarty-Lechner Kamill; 1963: Dunaújváros, B. Császár Ildikó, Hrecska József. Ahogy más tervezővállalatok jelentősebb iskolái is (pl. 1958: Pécs, Nyugati városrész, 16 osztálytermes általános iskola, Fodor László, Általános Épülettervező Vállalat; 1960: Ózd - Farkaslyuk, 6 osztálytermes általános iskola, Szekeres József, Lakóterv és Pécs - Mecsekalja, 8 osztálytermes általános iskola, Tillai Ernő és Szerdahelyi Károly, Pécsterv). ${ }^{118}$

A kérdés tehát, hogy miként is születhettek meg ezek, a korszak iskolaépítészetének meghatározó darabjai? Ebben az esetben minden bizonnyal elvethetjük a szokásos helyi slendriánság magyarázatát, már csak az építkezések számbelisége és jelentősége miatt is.

Az ellentmondás egyik lehetséges feloldásához azonban kissé hátra kell lépni, és onnan megpróbálni a válaszadást. Az első időkben, az ötvenes években nagyon egyszerü iskolatervek születtek, amelyek szinte létezésük tényével teljesítették az elvárt, szükséges feltételeket. Ekkor rövid idő alatt nagy mennyiségű épületet kellett felhúzni, ráadásul döntően vidéki kistelepüléseken, ahol sem az építési körülmények, sem pedig a (feltételezett) építészeti „elvárások” nem voltak túlzottan kifinomultak, és (tegyük hozzá) elhelyezkedésük miatt még repre- zentatív értéket sem képviseltek a politika számára. 1956, de különösen 1958 után azonban létrejött egy olyan status quo, ami az építészet helyzetét is megváltoztatta. Ez a cezúra, amit akár a "hosszú hatvanas évek" kezdetének tekinthetünk az építészetben is, nemcsak a modernista formanyelv szabadabb használatát, hanem a formákban és technológiákban megjelenő újítások megvalósításának és átvételének igényét és lehetôségét is jelentette. ${ }^{119}$ Ezeket az egyedi iskolaterveket (még így futólag is) áttekintve szembeötlö, hogy szinte mindegyik törekszik a jobb használhatóságot lehetővé tevő szerkezeti újítások, anyaghasználati újdonságok bevezetésére vagy csak kipróbálására, esetleg továbbfejlesztésére.

A tantermek optimális elhelyezése, a legpraktikusabb terem-folyosó arányok, a tökéletes megvilágítás megtalálása, a nagy forgalom lebonyolítására és közösségi rendezvények tartására is alkalmas, de a gyereksereg szünetekbeli elhelyezését még rossz idő esetén is megoldó, nagy légterű zsibongó, a változó pedagógiai igényeket kiszolgáló és bővítéseket is elbíró ideális épület megtervezése volt a cél. Az egy-, illetve kétoldali megvilágítás érdekében át kellett gondolni a termek folyosóhoz való csatlakozását, alakját. A hosszanti termek $(6 \times 9$ méteres $)$ mindkétféle megvilágítással tervezhetőek, a haránt elrendezésúek $(6,4 \times 8$ méteresek) inkább kétoldali megvilágításra alkalmasak. Ez utóbbiak azonban elnyújtott alakjuk miatt nem kedveztek a táblára való rálátásnak. A négyzetes termek elképzelése a tervasztalon maradt, így „szerkezeti-gazdaságossági-pedagógiai szempontból egyaránt megoldatlan problémaként jelentkeznek". ${ }^{120}$

Kérdésünk megértéséhez érdemes felkapni a fejünket Reischl Péter fenti soraira, vagyis a bennük megszólaló kritikai hangra, amely igen gyakori a korabeli szakfolyóiratokban. Hofer Miklós gyöngyösi iskolájáról például ezt olvassuk: „A használat azonban azt mutatta, hogy a ma még fennálló tanteremhiány, a 36-42 tanulólétszám gyakori túllépését teszi szükségessé, (...) [a megvalósult épület] azonban a létszám megnöveléséhez nem elegendő."121

Volt, hogy maga az építész látta be, hogy némileg eltért a várakozásoktól, s kezdte el magyarázni tervének - a fölösleges költekezés látszata mögött megbúvó - értékeit. Zalaváry Lajos például így ír a Csepel-csillagtelepi iskolájáról: a pillértávolságok növelése és a gazdaságos födémmegoldás „ellenére az épület nem lesz jóval olcsóbb a hasonló méretü épületeknél, mert a megtakarítás egy részét a homlokzatburkoló anyagokra fordítottuk. Az épület helye és egyrészt az a körülmény, hogy a lakótelep lakóépületeit a legszerényebb eszközökkel terveztük, másrészt a vasbetonváz-szerkezet indokolttá teszi, hogy az iskolát alul keresztmetszeti 
téglával, felül magát a vázat kemény kőburkolattal burkoljuk. A burkolandó felület mérete az épület kubatúrájához viszonyítva nem nagy, így még a karbantartási előnyökre se kellett hivatkoznunk ahhoz, hogy a beruházó vállalat is nemesebb burkolat alkalmazását engedélyezze. (...) Mi reméljük, hogy a gazdasági számításaink a végén mégis meghozzák a várt eredményt, és a Csillagtelepi iskola a jól funkcionáló és olcsó iskolák közé fog tartozni". ${ }^{122}$

Harmadszor pedig olvashatunk olyat is, amikor kiderül, az épület egy összetett problémafelvetésre adott válasz volt. Mogyoródon például „ez az iskola egyike annak a négynek - Mogyoród, Dunavarsány, Budakeszi, Pilisszentkereszt-, amelyek a Pestmegyei [sic!] Tanács VB megbízásaként egy müterembe kerülve, a tervező vezetésével - lényegében összefüggő - kísérletsorozatot alkotnak a harántrendszerben szerkesztett, lépcsősen eltolt ablakokkal egyoldalt világított, mély traktusú tantermek tartományában. A kísérlet több irányú volt. - Egyik iránya magát a tanterem korszerűbb formálását célozta: a hagyományos tantermekével azonos ablakfelülettel, de más elosztásban: egyenletesebb, jobb megvilágítást. - A hagyományossal azonos átlagmagassággal, de a jobb világításhoz igazított keresztmetszettel: jobb térhatást. - A négy kolumnás ülésrenddel: jobb nevelő-tanuló kapcsolatot. - Az egy teremre jutó rövidebb folyosószakasszal: gazdaságosabb folyosó-terem arányt (és egyben a tanteremsornak a rosszabb égtáj felőli teljes védelmét). - Az egyesített födém és födélhéjjal gazdaságosabb és korszerübb szerkesztést keresett. A kísérlet másik iránya az volt, hogy miként lehet különböző nagyságrendú iskolák igényeit ugyanazzal a szerkesztésmóddal, s az előzőek szerinti tanteremformálással kielégíteni. Mogyoródon a hattantermes iskola volt a feladat." A harmadik kísérleti irány a fütéssel kapcsolatosan a teljes központi fütés és a teljes kályhafütés közti megoldással próbálkozott. „További kísérleti cél: hogyan alakít változatos, artisztikus tereket a födémsík, mintegy »ingyen « a jobb világítást célzó elrendezés igényének természetes követésével. Végül a négy iskola közül kettőnél (Dunavarsány és Mogyoród) kísérleti cél volt annak vizsgálata, hogy a korszerü szerkesztési elvekből folyó formák hogyan illenek a magyar faluba. Fontos szerepet játszik ebben a tiszta fehér meszelés alkalmazása (kívül és belül)." ${ }^{123}$

A megépült iskolák gazdaságossági, funkcionális és olykor esztétikai megfelelőségének szemlézése és az épületek többé vagy kevésbé nyíltan felvállalt kísérleti jellege - úgy tünik - megadják a választ eredeti kérdésünkre. Eszerint korszakunk egyedi tervezésü épületei egy átfogóbb elgondolás részei, amely az ideális, de legalábbis optimális iskolaépület megvalósítását célozza.
Ezt a vélekedést támasztja alá az a tény is, hogy a jól sikerült példányok duplikálódhattak. Itt azonban célkitüzésben és a megvalósítás irányában is közelítünk másik épületcsoportunkhoz, a típustervekhez. Vajon elképzelhető-e, hogy ha hatékonyabb a központi irányítás, akkor ma Kismarty-Lechnert, Szroghot vagy Zalaváryt is típustervezőnek tartanánk, akik a Reischl és Kiss István által megkezdett úton járva korszerü iskolaépületekkel biztosították népünk iskolázottságának felvirágzását? A kérdés költői marad. Annyi komolyságot azonban mégis hordoz, hogy véleményem szerint Reischl Péter, Kiss István vagy a többiek típustervezői életmüvének ugyanúgy helye van a korszak építészettörténetében, mint azokénak, akiknek az iskolái csak egy vagy két példányban épültek fel. A tárgyalt épületanyagot a politikai és építésirányítási akarat, a pedagógiai elvárások vagy az építésügyi szabályozások felől nézve ugyanis jól látszik, hogy egyáltalán nem olyan mély a szakadék e kétféle tervezés között. A típustervek rossz híre ellen szól az a tény is, hogy történelmietlen egy olyan épületállományhoz köthető kérdésfelvetés lenézése vagy szőnyeg alá söprése, amely a magyarországi települések nagy részének képét meghatározza, és amely épületekben immár generációk szocializálódtak, és (tegyük hozzá) szoktatták a szemüket a hatvanas évek - és helyenként egyáltalán a modern építészet - tereihez, arányaihoz, tömegkapcsolásaihoz, ritmusaihoz, anyaghasználatához. ${ }^{124} \mathrm{~S}$ tették mindezt akkor, amikor a modern és újítás szavak erősen pozitív tartalmúak voltak.

Természetesen az építészeti minőség meghatározása különlegesen összetett kérdés. Az épületállomány mai megítélését nagyban befolyásolja a felhasznált anyagok kopása, az épületek állapota és jelenlegi használati értéke, összességében öregedésük mikéntje, az adott korok kihívásaihoz való alkalmazkodási képességük, vagyis formai és tartalmi időtállóságuk. Ám ott vannak a megszületésükkor érvényes megítélési tényezők is: azaz a tervező invenciójának eredetisége, az épület nemzetközi trendekhez és az aktuális helyi vizuális kánonhoz való viszonya. Egy további tanulmány feladata lenne feldolgozni a korszak építészetének külföldi kapcsolatait - jelen esetben -, a középület-tervező építészek tájékozódási horizontját, ${ }^{125}$ munkásságuknak a nemzetközi építészettörténetben betöltött helyét. Különösen azért, mert az iskolaépítészet tekintetében is számos külföldi tanulmányútra, elméleti együttmüködésre került sor a KGST-tagországokon belül, de azokon kívül is. ${ }^{126}$ Ráadásul láthatóan az akkori építészeti trendek és különösen az iskolaépítési tendenciák sem álltak annyira távol a most megismert magyar gyakorlattól, mint amennyire azt elsőre gondolnánk. 


\section{JEGYZETEK}

1 A dolgozat a Középülettervező Vállalat (KÖZTI) támogatásával, a vállalat történetét feldolgozó kutatás részeként íródott. Néhány helyen azonban a vizsgált anyagot kiegészítettem más vállalathoz tartozó építészek munkáival is.

2 Az ideiglenes nemzeti kormány 6650/1945. ME sz. rendelete az általános iskola szervezése tárgyában: Köznevelés 1945/1, 4, 7; Magyar Közlöny 1945/105. sz.

3 1951. évi 15. törvényerejű rendelet, 1959. évi 29. törvényerejü rendelet és 1961. évi III. tv. 3. §. Idézi: Kazuska 2012, 135

4 Kelemen 2007, 7.

5 1949. évi XX. tv. 48. § (1-2). a dolgozók művelődéshez való jogáról, a 50. § a nők jogegyenlőségéről szól.

6 1949. évi XXV. tv. 43. § (1-8).

7 1949. XXV. tv. 22. § (1). Hét területre irányoztak elő építőipari beruházást, amik közül ráfordítás alapján ez a terület az ötödik volt. Ipari építkezésre: 5919, lakásokra, lakóházakra (községfejlesztésre) 5130, közlekedésire 4475, mezőgazdaságira 3389, kulturális célúra 1391, kereskedelmire 270 millió, szociális célú építkezésekre pedig 771 millió forint esett.

8 1951. II. tv. 36. § (1-8). A gyáripari tanulók létszámát az 1949. évi 31 600-ról 1954-re 85 000-re, az iparitanuló-múhelyekben tanulók számát az 1949. évi 8200-ról az eredeti ötéves tervben elöírt 14900 helyett 32 000-re, a tanulóotthonok férőhelyeinek számát 6200-ról 10000 helyett 30 000-re, a középiskolai tanulók létszámát 45000 fö helyett 77000 fővel, az egyetemi és főiskolai hallgatók számát a tervidőszak alatt az eredeti ötéves tervben előírt 8000 fó helyett 30000 fóvel kell emelni.

9 1954. évi IV. 4. § (1-2): 10080 millió Ft; 1955. évi I. tv. 4. § (1-2): 10446 millió Ft) és 1956. II. tv. 4. § (1), (3): 11507 millió Ft.

10 1957. évi III. tv. 5. § (2c): 4067 millió forint; 1958. évi I. tv. 5. § (2d): 3719 millió (nincs szó építésről, csak fenntartásról és egyéb kiadásról).

11 1958. évi II. törvény az 1958-1960. évi hároméves népgazdaság-fejlesztési terv irányelveiről. 33. §. Óvodai férőhelyek növelésére és új gimnáziumi osztálytermek létesítésére a tervidőszak alatt csak korlátozott mértékben kerülhetett sor, a gyermekotthoni és a gyógypedagógiai hálózatot viszont tovább kellett fejleszteni (különös tekintettel a Fóti Gyermekvárosra). Az ezeket a célkitüzéseket forintosító éves költségvetési törvények: 1959. évi I. tv 5. § (2d): 3960 millió, 1960. évi I. tv. 5. § (2d): 4979 millió, 1961. évi I. tv. 5. § (2d): 5625 millió Ft.

12 1961. évi II. törvény a Magyar Népköztársaság második ötéves népgazdaság-fejlesztési tervéről az 1961. január 1-jétől 1965. december 31-ig terjedő időszakra.

13 1961. évi II. tv. 82. és 83. §.

14 Kádár 1962, 289. A megállapítás tényszerü valóságtartalmát minden bizonnyal árnyalja, hogy a beszéd a Kulich Gyula Kollégium ifjúsági gyưlésén hangzott el középiskolás korú hallgatóságnak.

15 1966. évi II. tv. 36. § (1.b).

16 1970. évi II. tv. 36. § (2): „Az óvodai ellátás már elért színvonalát az óvodáskorú gyermekek létszámának emelkedése mellett fenn kell tartani; ehhez 38-39 ezer új óvodai férőhelyet kell létesíteni."

171975 évi IV. tv. 49. §.
18 1980. évi III. tv. 47. §.

19 Külön tanulmányt érdemelne ezeknek a szabályozásoknak a részletes vizsgálata. Egyrészt az, hogy milyen mértékben jelennek meg a korabeli vizuális kánon elvárásai? (Pl. a környezetbe illeszkedés, parkosítás, az utcafrontot meghatározó belső térkialakítás.) Másrészt pedig vizsgálandók lehetnének a szabályozás történeti változásai is. Véleményem szerint ugyanis az egy főre jutó tér, a tágasság, a különböző funkciójú egységek elhelyezésének mikéntje nemcsak az adott korszak használati gyakorlathoz való hozzáállásáról, hanem környezetkultúrájáról, esztétikai elképzeléseiről is árulkodó lehet.

20 Balázs-Lenzsér 2004, 63.

21 OÉSz 1962, 46§ (1), 95.

$22 \mathrm{Az}$ Egészségügyi Minisztérium rendelkezéseiből még 1994-ben is a 8200-1/1953 (EüM) utasítás melléklete volt érvényben. Az építkezések szabályozása a 2/1986. (II. 27.) ÉVM rendelettel kötelező hatállyal kibocsátott OÉSz-ben, in: Pászti et al. 1994, 2.

23 8200-1/1953. (EüM) I/4. Uo. 15.

24 8200-1/1953. (EüM) II/1-2. és 5. Pászti et al. 1994, 16, 17. 25 8200-1/1953. (EüM) III/1-3. Pászti et al. 1994, 17-18.

26 8200-1/1953. (EüM) III/7. Pászti et al. 1994, 18.

27 8200-1/1953. (EüM) VIII. Pászti et al. 1994, 21.

28 8200-1/1953. (EüM) IX. Pászti et al. 1994, 22.

29 8200-1/1953. (EüM) XXV. Pászti et al. 1994, 38. Kötelezően betartandók: I/1-4., I/6-9., II/2-6., III/1-3., III/57., IV/1-3., V/1., VI/1-2., VII. VIII., IX., X., XI., XII/1-2., XIII/1., XIV/1-2., XVII/1-5., XIX/1., XX/1-2.

30 Az 1962-es utánnyomás, a kiadás eredeti dátumát az Országos Széchényi Könyvtár katalógusa sem segített kideríteni.

31 OÉSz 1962, 95.

32 OÉSz 1962, 110-111. 6/a. megadja a szélfogó méreteit is.

33 OÉSz 1962, 112.

34 OÉSz 1962, 143.

35 5/1974. (V. 24.) ÉVM XV. 29§ (10-11).

36 Általános 1963, 15.

37 Zalaváry 1958, 229.

38 „E célt szolgálták 1949-ben először megszerkesztett és 1951-ben átdolgozott 1952-ben jóváhagyott Tervezési normák [sic!]." Borbíró 1954, 234.

39 1949. XXV. tv. 22. § (2): „Meg kell valósítani az építészeti alkatrészek, szerkezetek előregyártását, meg kell szervezni az építmények tipizálását és olyan eszközökkel kell az iparágat ellátni, hogy lehetővé váljék az építőmunka idényszerüségének megszüntetése."

40 Típustervek 1951. június, 1952. július. Az idézet $(1952,6$.) nemcsak a rendelkezések alapossága miatt érdekes, hanem amiatt is, mert megjegyzi, hogy „A rendelet értelmében a Típustervek Katalógusa 1951. I. Közlemény is hatályát veszti". Ez pedig mintha éppen a hosszú távra szóló, emiatt (is) gazdaságos tervek elképzelésének mondana ellent.

41 Borbíró 1954, 234. A szerző kifejti, hogy nemcsak az a baj, hogy a 16 különböző fajtájú általános iskolánál (98 tanteremmel) a tervekben feltüntetett tiszta hasznos terület 16\%-kal nagyobb, mint az 1952. évi tervezési normák szabályozta hasznos terület - és így drágább az épület -, hanem „megállapítottuk azt is, hogy az említett tervezési 
normák messzemenően túlhaladják a szovjet típustervekből és tervezési normákból kiolvasható előírásokat".

42 2044/1958. (V. 25.) sz.

43 Bánszky-Zólyomi 1962, 4.

44 Gyöngyösi 1961, 29-30. A típustervezés korabeli szakirodalma terjedelmes (Bozi 1961, Csordás 1961 etc.), feldolgozása a későbbiekben szükséges, itt azonban terjedelmi okokból csak egy részét lehetett figyelembe venni.

45 1964. évi III. tv. A típustervezés, 43. § (1-2).

46 Hegedüs 1958, 241-242. Szeretném elkerülni ennek az - építőipari szempontból is - összetett korszaknak a sablonos megítélését, annyi azonban az eddigiek alapján is kijelenthetö, hogy az országban sem térben, sem időben nem volt azonos színvonalú a központi tervek alkalmazása, illetve megvalósításának minősége.

47 Maróti 1963. Ugyanő tárgyalja az adaptálások anomáliáit is, mint pl. a jászberényi 12 tantermes iskola színorgiáját.

48 Egy-és kéttantermes: 51. IV.914,915. négytantermes: 52. III. 25. Típustervek 1952, 25-26/a.

49 Minisztertanácsi 2004, 291. és 273/36. p. 293.

50 Valentiny 1958, 86-89.

51 Csaba 1978, 306.

$52 \mathrm{Az}$ együttműködésről az ÉM Kutatóintézeteinek katalógusai (1957-1972) is tájékoztatnak. Ezekben a típustervezés és tipizálás problémakörére gyakran visszatértek, és a középületekkel kapcsolatosan a KÖZTI vett részt rendszeresen az iskolákkal kapcsolatos tanulmányok elkészítésében. Többek közt 1957-1961-ben az Iskolák, óvodák, bölcsődék méretegységesitése és tipizálások elókészitése elnevezésü kutatásban, melynek témavezetője a TTI, az együttdolgozó intézete pedig a KÖZTI. A kutatás célja a három épülettípus méretkoordinált axisrendszerének kidolgozása tipizált szerkezetek alkalmazásának előkészítéséhez, feladata a „hazai és külföldi tervek és alkalmazott irányelvek összehasonlítása alapján a magyar viszonyokra a legmegfelelöbb paraméterek megállapítása". Az 53 oldalas, 43 ábrával ellátott tanulmány megállapította a funkcionális fő paramétereket, és meghatározta a paraméterekhez alkalmazandó axisrendszereket. Javaslata alapján az 1962-ben készülő típusterveknél ezek már felhasználhatóak. Csorba 1963, 140, 26; 02.01.AG OTTKT 14.3 TTI számú kutatás.

53 Katona 1969, 112.

54 45/1961. (XII. 9.) Korm. számú rendelet és annak végrehajtására kiadott 1/1961. (XII. 9.) OT-PM-ÉM. számú együttes rendelet Vhr. 54. §. (3).

55 Szávuly 1964, Bevezető (oldalszám nélkül).

56 Hegedüs 1968, 235.

57 Jeney 1990, 85-92. és Jeney 2000, 7-11. A vélemény súlyából valamelyest visszavesz, hogy a szerző lényegében ugyanazt a szövegét jelentette meg tíz év eltéréssel ezen a két fórumon. „A típustervek alkalmazása részben beváltotta a hozzá füzött reményeket, egyúttal számos építészeti problémát hozott felszínre (uniformizálás, ugyanolyan épületek megjelenése városon és falun, a környezethez való alkalmazkodás hiánya stb.)."

58 Ferkai 1987, Gerle 1987, Lantos 2009.

$59 \mathrm{Ez}$ a rendelet is kitért a megfelelő helyszín kijelölésére és az iskola fenntartására (Ratio 1913, LXX. és LXXIII. §.), és arra is, hogy ahol helyi fenntartás nem lehetséges, a tanulmányi kincstár fog segélyt nyújtani. Ám a tervezésről itt nem esik szó. Kelényi említ egy 1786-os kancelláriai levelet, amely a Magyarországon építendő templomokhoz, iskolákhoz és paplakokhoz kér terveket három változatban. F. A. Hillebrandt válaszleveléből tudható, hogy 1785-ben már voltak ilyenek. 1773-ból példát is hoz iskola típustervének meglétére. Kelényi 2013, 487.

60 38. törvénycikk 1 . § „Minden szülő vagy gyám, ide értve azokat is, kiknek házában gyermekek mint mestertanítványok vagy házi szolgák tartatnak, kötelesek gyermekeiket vagy gyámoltjaikat (...) nyilvános iskolába járatni, életidejök 6-ik évének betöltésétől egész 12-ik, illetőleg 15-ik év betöltéséig."

61 Pőcze 1987, 15. és Sváb 1914, 23.

62 Gerle 1987, 18.

63 Pl. Budapesten 1909 és 1912 közt három, ősztől őszig tartó ciklusban 55 új iskola épült fel 27 millió korona költséggel. Ebből 36 önálló, többemeletes iskola volt (11-14 tanteremmel), 15 barakkiskola. Gerle 1987, 17.

64 Ferkai 1987, 21.

65 1926-os VII. törvénycikk: a mezőgazdasági népesség érdekeit szolgáló népiskolák létesitésérōl és fenntartásáról. 1. §: „,népiskola állítása és építése hivatalból mindenütt elrendelhető, ahol (...) legalább másfél, legfeljebb négy kilométer sugarú területen (körzetben) szétszórtan vagy tömörülve az utolsó három év átlagát számítva legalább 20 család vagy 30 (...) tanköteles lakik és a körzeten belül valamenynyi tanköteles befogadására alkalmas más iskola nincs."

66 1926. VII. tc. 5. §.

67 1926. VII. tc. 11. §.

68 Ferkai 1987, 21.

69 Ferkai 1987, 22.

70 Zátonyi 2006, 53.

71 Sváb 1914, 18.

72 Szávuly 1964, Katona 1969.

73 Pl. Kelemen 2007, 9. „A kis létszámú, összevont tanulócsoportos iskolák száma (...) 1950 és 1970 között 1133-ról 1376-ra nőtt." Ő 20 évre számol annyi épületet, mint amennyi osztálytermet az Iskolakutatás az adott időszak egy évére, ez pedig akkor sem lehet pontos adat, ha az épületek nagyságával, a tanteremszámokkal pro vagy kontra operálunk.

74 Kiss-Jeney 1968, 13. és 34. Az ő számításaikhoz közelít Zólyomi Alfonz számadata is, ami a Magyar Építőmüvészet 1961-es Iskola-számában jelent meg. Eszerint „az 1960-ban befejezett hároméves tervben évente már 800-1000 általános iskolai tanterem épült állami erőből". Zólyomi 1961, 3.

75 Kiss-Jeney 1968, 31-33. Az alaptervek módosított verzióival együtt ez a szám 30.

76 Magyar Országos Tervezési Irányelvek (a továbbiakban MOT. I.) 3-3, 3-4, 3-5, 3-6, 3-7/59. Építésztervezője Reischl Péter (KÖZTI-TTI), kidolgozója a KÖZTI.

77 Kiss-Jeney 1968, 40. és 41-42.

78 MOT. I. 3-8/59-60, 3-27/60, 3-28/60, 3-9/59-61, 3-10, 3-12, 3-13, 3-16, 3-30, 3-19/59.

79 MOT. I. 3-8/59-60, MOT. I. 3-27/60, MOT. I. 3-28/60. (Ugyanazon terv változatai.) Kiss-Jeney 1968, 47.

80 MOT. I. 3-9/59-61 és MOT. I. 3-38/60. (Ugyanazon terv változatai.) Kiss-Jeney 1968, 45-46.

81 MOT. I. 3-12/59 és 3-13/59. Érdemes megemlíteni, hogy a Gönczy-féle mintatervek közt is található mindkettőre példa, amiket, ahogy az 1897-es mintatervek többoldali megvilágítású verzióit is 1928-ban Benisch mint elborzasztó példákat emleget. Benisch 1928, 99, 103. 
82 MOT. I. 3-16/ 59-60, 3-29/60-61-64, 3-30/59-60-61-64. Kiss-Jeney 1968, 48-49.

83 MOT. I. 3-18/59-64 és MOT. I. 3-19/59-64. Kiss-Jeney $1968,43$.

84 MOT. I. 3-60/61; MOT. I. 56-3/63; MOT. I. 56-4/63:

8-12 tantermes nagyblokkos általános iskola.

85 MOT. I. 56-6/64. Zólyomi-Székely-Máriás 1965, 48-51.

86 MOT. I. 56-9/64. Uo. 80-81.

87 Kiss-Jeney 1968, 32. Az 1965-ben épültekről nincs adat (126.); 1966: 129.

88 Összehasonlítva a korábbi típustervekkel, az 1868. évi XXXVIII. tc. 27. §. elöírása: „Az ujonnan építendő iskolaépületek egészséges helyen épültek, szárazak s a gyermekek létszámához mérten (egy teremre 60 gyermeket, s minden gyermekre legalább is 8-12 négyszögöl lábnyi [0,8-1,2 m² L. E.] helyet számítva) elegendő számú tágas, világos és könnyen szellőztethető tantermekkel legyenek ellátva." A Gönczy-féle 1870-es tervek közt nyolcvan férőhelyes tanterem is van, méretük pedig 3,8-4×6,9-9,2 m. Az 1897-esekre vonatkozó előírás $12 \times 6,3-6,5$ méterest tart ideálisnak 3,8-4 m belmagasság mellett. Benisch $1928,99,103$. A századfordulón épült, 48-60 főre méretezett iskolai tantermek átlagosan $65 \mathrm{~m}^{2}$ alapterületüek és általánosságban 4 méter belmagasságúak voltak, így egy gyermekre 1,2-1,5 $\mathrm{m}^{2}$ alapterület és $5,6 \mathrm{~m}^{3}$ légtér jutott. Gerle 1987, 17.

89 MOT. I. 3-13/59. Reischl Péter, MOT. I 3-30/61. Reischl Péter és Domonkos Jenő, illetve MOT. I. 56-6/64.

90 Kiss-Jeney 1968, 58.

91 Kismarty-Lechner Kamill 1995-ben kapott Ybl-díjat a „,több, mint fél évszázados, kiemelkedő jelentőségű és összegező, az építészek gondolkodására termékenyítőleg ható iskolák tervezéséért". Schéry 1995, 446.

92 Kismarty-Lechner 1987. Eszerint a szikszói iskola 1948-49-ben épült, de a KÖZTI adattára szerint Kismarty 1958-ban tervezett iskolát Szikszóra. Kismarty 1960-1963ban dolgozott a KÖZTI-nél.

93 Kiss-Jeney 1968, 55. és 60-61, továbbá SzárayZólyomi 1970, 56. szerint a X. Kőbányai úti (ma Szervátiusz Jenő Általános) iskolát 1960-ban tervezte KismartyLechner, és az épült meg hamarabb, a XXIII. kerületi Sodronyos úti (ma Mikszáth Kálmán Általános Iskola) pedig csak 1962-ben készült el. Szendrői szerint viszont a Sodronyos úti épült fel korábban. Annak a tervezési éve: 1948, kivitelezéséé: 1949. Szendrői 1972, 90. Kismarty cikkében a Sodronyos utcait 1955-1957-re, a Kőbányai útit 1958-1960-ra datálja, a hagyatékában fennmaradt néhány fotón található sajátkezü feljegyzései pedig ezek: „Sodronyos úti iskola 1955-58” és „Köbányai úti iskola 1957". Kismarty 1987, 25. Ez a datálási bizonytalanság azonban nemcsak az ô életművére, hanem sajnálatos módon mindazokéra jellemző, akiknél levéltári anyag hiányában csak a meglévő szakirodalomra, illetve visszaemlékezésekre támaszkodhatunk.

94 Kiss-Jeney 1968, 60-61.

95 Brödner-Kroeker 1951, 87.

96 Általános iskola, Thayngen, 1950-1952, tervező: Ernst Gisel (Zürich). Brödner-Kroeker 1951, 123-128.

97 Kiss-Jeney 1968, 56, Száray-Zólyomi 1970, 52, Merényi 1969, 136. (397. kép) egyetért abban, hogy az épület 1962-es, de Kismarty 1987-es cikkében 1959-60-ra datálja. Kismarty-Lechner 1987, 25. Ezt az a tény erősíti meg, hogy a hagyatékban fennmaradt az érdi 16 tantermes gimnázium terve 1962-es keltezéssel, mely ennek egy kópiája volt.

98 Kiss-Jeney 1968, 67-68.

99 Kismarty-Lechner 1987, 26.

100 Reischl Ybl-díja: I. fokozat, „a Fóti Gyermekváros tervezéséért és a 8 tantermes általános iskola típustervéért", 1960. Schéry 1995, 130. A nyolctantermes általános iskola típusterv tervezője a KÖZTI, Reischl Péter és Domonkos György, tervezés ideje: 1960. A terv egy korábbi típusterv továbbfejlesztése, kiegészítése a gyakorlati oktatás helyiségeivel. Több ütemben építhető (4+4 tanterem + tornaterem és mühelyek + konyha). Téglafalas szerkezetü, előregyártott födémmel. A MOT I. 3-29/60 jelü típusterv 1961. XII. 18. és 1977. VIII. 31 között volt hatályban.

101 Kiss-Jeney 1968, 6, Száray-Zólyomi 1970, 81-85. Fotó az iskoláról: 84

102 Kiss-Jeney 1968, 65-66.

103 Kiss István Ybl-díja II. fokozat, „a kaposvári uszoda és könyvtár tervezéséért, továbbá a középületek, létesítmények tipizálását és méretegységesítését elősegítő kezdeményező elméleti tevékenységéért", 1967. Schéry 1995, 201.

104 Kiss-Jeney 1968, 55.

105 Kiss-Jeney 1968, 64-65.

106 Kiss-Jeney 1968, 55, Száray-Zólyomi 1970, 55. Kismarty cikke szerint 1960-1962-es. Kismarty-Lechner 1987, 3.

107 II. fokozat, ,, a budakeszi 8 tantermes iskola tervéért", 1. Schéry 1995, 143. A Magyar Építőipar cikke szerint tervei 1958-ban készültek, kivitelezése 1959-60 közt zajlott. Szemelvények 1960 1961, 29.

108 Kiss-Jeney 1968, 63-64.

109 Merényi 1969, 136. (398. kép) szerint az iskola 1960 -as, viszont Kismarty szerint 1959-1961-es. KismartyLechner 1987, 3. A datálás kérdését a Szemelvények 1961, 1962, 21. döntötte el a „Mogyoród, 6 tantermes általános iskola" szakaszával.

110 Szemelvények 1961 1962, 21.

111 Szendrői 1972, 95, statikus: Szőke Dezső (KÖZTI), Zalaváry 1958, 229-232.

112 Száray-Zólyomi 1970, 53. Reischl Péter cikke szerint az eredeti tervek 1955-ösek, és egy áttervezett verziót építettek fel végül. Reischl 1960, 223-226.

113 Mányoky 1961-ben Ybl-díjat kapott ezért az épületért: II. fokozat, ,,az egri iskola és a középület-tervezés területén kifejtett működéséért". Schéry 1995, 144.

114 Száray-Zólyomi 1970, 57.

115 Kiss-Jeney 1968, 55, Száray-Zólyomi 1970, 58.

116 Kiss-Jeney 1968, 62-63.

117 Szemelvények 1960 1961, 26-27.

118 Száray-Zólyomi 1970, 47, 54, 62.

119 „A hatvanas évek a fellendülés, az optimista tervezgetés és a nagy volumenü építés korszaka volt." Ferkai 1985, 25. Ugyanott megjegyzi, hogy „,az új feladatok lehetőséget adtak a kísérletezésre is", példái közt pedig típustervek (Szrogh György, Pintér Béla és Hegyi Lajos óvoda-bölcsőde típustervei) és egyedi épületek (Kismarty és Szrogh iskolái) egyaránt megtalálhatóak.

120 Reischl 1961, 4.

121 Szemelvények 1959 1960, 27.

122 Zalaváry 1958, 229-230.

123 Szemelvények 1961 1962, 21.

124 Ugyanitt nem szabad megfeledkeznünk arról a tényről sem, hogy a korszakban ez az épületanyag is 
része volt a kormányzat sikerét hirdető propagandának, a hatalmi reprezentációnak. Szándékosan válogattam illusztrációként a korszak képeslapjaiból, amelyek az egyes települések fejlődését, azok háború utáni megújult képét mutatják be, s melyeken a legeldugottabb települések legegyszerúbb épületei is megjelentek. Az a tény, hogy a MOT. I. 3-16/59. típusról és annak változatairól a Szerencsi Képeslapgyüjtemény 15 városból 33-féle ké- peslapot őriz, rámutat, hogy a téma további vizsgálatot érdemel.

125 Erről korábban 1. Lantos 2006.

126 Pl. Reischl Péter a típustervezés angliai, francia tapasztalatairól ír: Reischl 1962. Kiss István az 1962-es Londoni Nemzetközi Iskolaépítési konferencián járt: Kiss 1962; Szrogh György pedig a USA-beli iskolaépítést ismerteti az Iskolaépítés 2. kötetében: Szrogh 1969.

\section{RÖVIDÍTVE IDÉZETT IRODALOM}

Általános 1963 - Általános iskolák. Magyar Országos Tervezési Irányelvek. Budapest 1963.

Balázs-Lenzsér 2004 - Balázs Mihály - Lenzsér Péter: Oktatási épületek. In: Cságoly Ferenc szerk.: Középületek. Budapest 2004, 62-109.

Bánszky-Zólyomi 1962 - Bánszky Zoltán - Zólyomi Alfonz (szerk.): Művelődésügyi típustervek katalógusa. Budapest 1962

Benisch 1928 - Benisch Artúr: Az iskolaépítési akció. In: Magyar Népoktatás. Budapest 1928, 99-125.

Bozi 1961 - Bozi József: A típustervezés feladatai. Műszaki Értesítő 1. 1961/1, 3-4.

Borbíró 1954 - Borbíró Virgil dr.: Az általános iskolák új tervezési irányelvei. Magyar Építőipar 3. 1954/6, 234-237.

Brödner-Kroeker 1951 - Erika Brödner - Immanuel Kroeker: Schulbauten. München 1951.

Csaba 1978 - Csaba László: Tervezésfejlesztési és Típustervező Intézet (TTI). In: Kubinszky Mihály dr. (szerk.): Modern Építészeti Lexikon. Budapest 1978, 306-309.

Csorba 1963 - Csorba Emánuel [et al.] szerk.: Az Építésügyi Minisztérium kutatóintézeteinek katalógusa az 195761. években kidolgozott kutatási témákról (3 kötet). 1. kötet. Budapest 1963.

Csordás 1961 - Csordás Tibor: A típustervezés gyakorlata. Müszaki Értesítő 1. 1961/1, 9-16.

Ferkai 1985 - Ferkai András: Negyven év magyar építészete. Magyar Építőművészet 33. 1985/2, 22-27.

Ferkai 1987 - Ferkai András: Iskolák a két világháború között. Magyar Építőművészet 35. 1987/3, 21-24.

Gerle 1987 - Gerle János: Iskolaépítés a századfordulón. Magyar Építőmüvészet 35. 1987/3, 17-20.

Gyöngyösi 1961 - Gyöngyösi István dr.: A típustervezés tömeges építés néhány kérdése. Magyar Építőművészet 9. 1961/2, 29-30.

Hegedüs 1958 - Hegedüs Ernő: Néhány szó a vidéki kis iskolák építéséről. Magyar Építőipar 7. 1958/6, 237-245.

Hegedüs 1968 - Hegedús Béla: Épületekkel szemben támasztott követelmények meghatározása. In: Kunszt György: Építéstudomány és építésiparosítás. A magyar építési kutatás 20 éve. Budapest 1968, 225-237.

Jeney 1990 - Jeney Lajos: A magyar iskolaépítés közelmúltja. Kortárs 34. 1990/5, 85-92.

Jeney 2000 - Jeney Lajos: Típustervek, reformok, kutatások. Köznevelés 56. 2000/14, 7-11.

Kádár 1962 - Kádár János: Társadalmunk fontos feladata az oktatási rendszer fejlesztése. Köznevelés 38. 1962/10, 289-291.

Katona 2012 - Katona József szerk.: Építésiparosítás, müszaki tervezés, tipizálás. Budapest 1969.

Kazuska 2012 - Kazuska Melinda: A tankötelezettség múltja, jelene és jövője. Miskolci Jogi Szemle 7. 2012/1, 128-142.
Kelemen 2007 - Kelemen Elemér: Az általános iskoláról - a 60. évforduló után. Iskolakultúra 16. 2007/5, 3-15.

Kelényi 2013 - Kelényi György: Típustervek a magyar későbarokk építészetben. In: Szentesi Edit - Mentényi Klára - Simon Anna szerk.: Kő kövön. Dávid Ferenc 73. születésnapjára. Budapest 2013, 485-494

Kismarty-Lechner 1987 - Kismarty-Lechner Kamill: A II. világháború utáni iskolaépítés néhány adata. Magyar Építőművészet 35. 1987/3, 25-28.

Kiss-Jeney 1968 - Kiss István - Jeney Lajos szerk.: Iskolaépítési kutatás. Budapest 1968.

Kiss 1962 - Kiss István: Iskolareform és iskolaépítés. Budapest 1962.

Kiss 1969 - Kiss István: Iskolaépítés Nagybritanniában (sic!). In: Kiss-Jeney 1968, 139-281.

Lantos 2006 - Lantos Edit: A magyar építészek tájékozódási horizontja 1957 és 1965 közt. In: Lantos Edit-Uhl Gabriella szerk.: Postera crescam laude recens. Tanítványi tisztelgés Keserü Katalin születésnapjára. Budapest 2006, 82-110.

Lantos 2009 - Lantos Edit: Müvelődésügyi tipizálás, Nyitott társadalomtörténet 3. Az ELTE Társadalomtörténeti Doktori Iskola Doktoranduszainak konferenciája. ELTE BTK 2009 [előadás]

Maróti 1963 - Maróti György: Típustervek adaptálásának tapasztalatai. Müszaki Tervezés 2. 1963/12, 31.

Merényi 1969 - Merényi Ferenc: A magyar építészet. 18671967. Budapest 1969.

Minisztertanácsi 2004 - Minisztertanácsi jegyzőkönyvek napirendi jegyzékei 1947. június 1. - 1950. február 25. (2 kötet) 1. kötet. (A Magyar Országos Levéltár Segédletei 11/2.) Budapest 2004.

OÉSz 1962 - Országos Építésügyi Szabályzat, II. kötet. Építési előírások 1. Általános előírások 2. Épületek. Budapest 1962.

Pászti et al. 1994 - Pászti József - Bereczki Sándor - König Beáta Laura: Az oktató-nevelő intézményekre vonatkozó közegészségügyi, építési és üzemeltetési előírások (szabványok) gyújteménye. Budapest 1994.

Pőcze 1987 - Pőcze Gábor: „....mint ezer bástya, mely véd” - Egy kilencven éves oktatáspolitikai döntés anatómiája. Magyar Építőművészet 35. 1987/3, 13-16.

Ratio 1913 - Az 1777-iki Ratio Educationis (ford.: Friml Aladár, dr.). Budapest 1913.

Reischl 1960 - Reischl Péter: Sztálinvárosi 32 tantermes iskola. Magyar Építőipar 9. 1960/4, 223-226.

Reischl 1961 - Reischl Péter: Iskolatervezésünk gyakorlata. Magyar Építőmüvészet 9. 1961/3, 36-37.

Reischl 1962 -Reischl Péter: Általános iskolák és diákotthonok méretegyesítése Angliában és Franciaországban. Müszaki Tervezés 1. 1962/12, 34-37. 
Schéry 1995 - Schéry Gábor szerk.: Évek, müvek, alkotók. Ybl Miklós-díjasok és müveik 1953-1994. Budapest 1995.

Sváb 1914 - Sváb Gyula: Újabb állami népiskolák. Magyar Mérnök és Építész Egylet Közlönye XLVIII. 1914/2, 17-32.

Szávuly 1964 - Szávuly Lajos szerk.: Tipizálás Magyarországon. Budapest 1964.

Szemelvények 19591960 - Szemelvények az 1959-ben épült létesítményekből. Magyar Építőipar 9. 1960/1, 1-48.

Szemelvények 19601961 - Szemelvények az 1960. évben épült létesítményekből. Magyar Építőipar 10. 1961/1, $1-47$.

Szemelvények 19611962 - Szemelvények az 1961. évben épült létesítményekből. Magyar Építőipar 11. 1962/1, $1-44$.

Szendrői 1972 - Szendrői Jenô: Magyar építészet. 19451970. Budapest 1972.
Szrogh 1969 - Szrogh György: Alsófokú és középfokú iskolák az USA-ban. In: Kiss-Jeney 1968, 281-313.

Típustervek 1951 - Típustervek katalógusa. Budapest 1951.

Típustervek 1952 - Típustervek katalógusa. Budapest 1952. Valentiny 1958 - Valentiny Károly: A müszaki tervezés állami szervezete. Magyar Építőipar 7. 1958/3, 86-89.

Zalaváry 1958 - Zalaváry Lajos: Csepel Csillagtelepi 24 tantermes általános iskola. Magyar Építőipar 7. 1958/6, 229-232.

Zátonyi 2006 - Zátonyi Sándor: Hatvan éves az általános iskola. Iskolakultúra 15. 2006/2, 49-58.

Zólyomi-Székely-Máriás 1965 - Zólyomi Alfonz - Székely Ferenc - Máriás János: Müvelődésügyi típustervek katalógusa. Budapest 1965.

Zólyomi 1961 - Zólyomi Alfonz: Iskolaépítés a Népi Demokratikus Magyarországon. Magyar Építőmüvészet 9. 1961/3, 3 .

\section{PLANNING SCHOOLS IN HUNGARY AFTER 1945: TYPES AND INDIVIDUAL BUILDINGS}

The paper deals with school construction in Hungary between 1945 and 1964, with greater emphasis on type plans. First the factors influencing school planning and the plans themselves are introduced. From among the legal provisions and government measures, the orders on compulsory schooling determined the volume of constructions. The design of a school building is always influenced by building law regulations, fire protection, usage safety and sanitary prescriptions. They determine the positioning of the building, the size of classrooms and common rooms, their illumination and place within the building.

The beginning of state-ordered school construction goes back to 1777 . The centrally ordered plans were always connected with educational reforms, also in the late $19^{\text {th }}$ century and the first half of the $20^{\text {th }}$ century as well as after World War II.

Each of the large planning companies initiated by the government after 1945 received a special architectural profile. School planning was the task of KÖZTI (Planning Office of Public Buildings), but owing to gaps in the bureaucratic regulations architects employed by other planning companies (Pécsterv, Mezőterv, Városterv, etc.) did also produce school plans in addition to KÖZTI architects. The same applies to TTI, the Type Planning Institute. The planning of school types began in 1949, but the use of types of different sizes and solutions was only compulsory in 1958 and 1964. Through the description of individual plans and realized buildings, the paper presents the different plan types which included a considerable number of original and high-quality designs. Even when type plans became compulsory, the number of schools built on individual plans did not decrease. Through the detailed description and scholarly analyses of several individual buildings, it can be confirmed that single plans did not decrease because their formal and technical solutions were attempts at the modernization of school planning. The author stresses that the successful plans were realized at several places, which might indicate that the original goal was the reproduction of the most up-to-date and economical models in large numbers. The leading architects who planned schools included Péter Reischl and István Kiss (type and individual plans), Kamill Kismarty-Lechner, István Brjeska, György Szrogh and Lajos Zalaváry. In their schools they applied the newest formal idiom of contemporary international school design (bilateral lighting with shifted floors, slanting half-gable roof over a complex building mass, surfaces faced with lasting natural materials, contemporary art works for decoration).

By way of a conclusion, the paper raises the possibility and need for the examination of school construction in the period from the viewpoints of building use, effects of schools and their role in the universal architectural history of the period.

LANTOS Edit müvészettörténész, MTA KIK Magyar Tudományos Müvek Tára / art historian, Library and Information Centre of the Hungarian Academy of Sciences, Hungarian Scientific Bibliographic Database, lantos.edit@hotmail.com

Kulcsszavak: iskolaépítés, típustervezés, modern építészet, építésszabályozás, építészeti tervezés, KÖZTI, TTI, Reischl Péter, Zalaváry Lajos, Kismarty-Lechner Kamill, Kiss István, Szrogh György / Keywords: school construction, type planning, modern architecture, building rules, architectural planning, KÖZTI, TTI, Péter Reischl, Lajos Zalaváry, Kamill Kismarty-Lechner, István Kiss, György Szrogh 